\title{
A global climatology of tropospheric and stratospheric ozone derived from Aura OMI and MLS measurements
}

\author{
J. R. Ziemke ${ }^{1,2}$, S. Chandra ${ }^{2,3}$, G. J. Labow ${ }^{4}$, P. K. Bhartia ${ }^{2}$, L. Froidevaux ${ }^{5}$, and J. C. Witte ${ }^{4}$ \\ ${ }^{1}$ Goddard Earth and Sciences Technology and Research, Morgan State University, Baltimore, Maryland, USA \\ ${ }^{2}$ NASA Goddard Space Flight Center, Greenbelt, Maryland, USA \\ ${ }^{3}$ Goddard Earth Sciences and Technology, University of Maryland Baltimore County, Baltimore, Maryland, USA \\ ${ }^{4}$ Science Systems and Applications, Inc., Lanham, Maryland, USA \\ ${ }^{5}$ NASA Jet Propulsion Laboratory, Pasadena, California, USA
}

Received: 23 May 2011 - Published in Atmos. Chem. Phys. Discuss.: 24 June 2011

Revised: 30 August 2011 - Accepted: 2 September 2011 - Published: 8 September 2011

\begin{abstract}
A global climatology of tropospheric and stratospheric column ozone is derived by combining six years of Aura Ozone Monitoring Instrument (OMI) and Microwave Limb Sounder (MLS) ozone measurements for the period October 2004 through December 2010. The OMI/MLS tropospheric ozone climatology exhibits large temporal and spatial variability which includes ozone accumulation zones in the tropical south Atlantic year-round and in the subtropical Mediterranean/Asia region in summer months. High levels of tropospheric ozone in the Northern Hemisphere also persist in mid-latitudes over the eastern part of the North American continent extending across the Atlantic Ocean and the eastern part of the Asian continent extending across the Pacific Ocean. For stratospheric ozone climatology from MLS, largest column abundance is in the Northern Hemisphere in the latitude range $70^{\circ} \mathrm{N}-80^{\circ} \mathrm{N}$ in February-April and in the Southern Hemisphere around $40^{\circ} \mathrm{S}-50^{\circ} \mathrm{S}$ during August-October. Largest stratospheric ozone lies in the Northern Hemisphere and extends from the eastern Asian continent eastward across the Pacific Ocean and North America. With the advent of many newly developing 3-D chemistry and transport models it is advantageous to have such a dataset for evaluating the performance of the models in relation to dynamical and photochemical processes controlling the ozone distributions in the troposphere and stratosphere. The OMI/MLS gridded ozone climatology data are made available to the science community via the NASA Goddard Space Flight Center ozone and air quality website http://ozoneaq.gsfc.nasa.gov/.
\end{abstract}

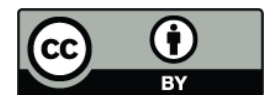

Correspondence to: J. R. Ziemke (jerald.r.ziemke@nasa.gov)

\section{Introduction}

In a previous paper Ziemke et al. (2006) combined ozone measurements from the Ozone Monitoring Instrument (OMI) and Microwave Limb Sounder (MLS) onboard the Aura satellite to obtain global maps of tropospheric column ozone (TCO). The derivation of TCO was based upon a tropospheric ozone residual (TOR) method which involved subtracting MLS stratospheric column ozone (SCO) from OMI total column ozone after adjusting for calibration differences between the two instruments. The TOR concept, which was first applied by Fishman et al. (1990) involved measurements of total and stratospheric column ozone from two separate instruments on two separate satellites. Total column ozone was obtained from the Nimbus 7 TOMS UV backscatter instrument while SCO was obtained from Stratospheric Aerosols and Gas Experiment (SAGE) occultation instrument. Aside from calibration issues involving the use of two different satellite measurements, there was also a serious constraint in producing global data with adequate temporal and spatial coverage. Although TOMS total column ozone was daily with near global coverage, SAGE SCO measurements were limited to $\sim 30$ ozone profiles per day with about one month required to cover the latitude range $50^{\circ} \mathrm{S}-50^{\circ} \mathrm{N}$. Chandra et al. (2003) later combined total column ozone from Nimbus 7 and Earth Probe TOMS with Upper Atmosphere Research Satellite (UARS) MLS ozone measurements to derive improved measurements of TCO extending from the tropics to the extra-tropics; that study was the first to use MLS ozone measurements to derive a long record of TCO spanning $\sim 6$ years. Having essentially coincident measurements along each orbital track with current Aura OMI and MLS column ozone is a significant improvement from these previous

Published by Copernicus Publications on behalf of the European Geosciences Union. 
studies in the ability to produce global maps of TCO from daily to longer timescales.

The study by Ziemke et al. (2006) used 2-D interpolation of MLS ozone to derive fields of SCO prior to deriving TCO. This method involved first applying a moving Gaussian interpolation to fill in missing MLS measurements along each daytime orbital track (on average about 14.6 south-to-north orbital tracks per day) followed by linear interpolation along longitude. This simple interpolation scheme for deriving daily gridded SCO fields works well provided that horizontal gradients in SCO are small. Meaningful daily maps of SCO can be determined from 2-D interpolation excluding regions of polar night and the tropospheric wind jets. Other methods have been introduced for obtaining daily maps of SCO and TCO with a major goal of improving measurements in the dynamical wind jet regions. Schoeberl et al. (2007) introduced a wind trajectory scheme using MLS ozone profiles and showed improvements for daily SCO and TCO in the extra-tropics. More recently Liu et al. (2010) describe an OMI-only ozone profile retrieval algorithm to derive daily fields of TCO and SCO. Other methods include data assimilation such as from the NASA Global Modeling and Assimilation Office (GMAO) (Stajner et al., 2008; Doughty et al., 2011) and also Aura TES ozone profile measurements (e.g., Kulawik et al., 2006). Despite data quality concerns regarding dynamical wind jet regions, TCO derived from even the simple interpolation method has resulted in many recent studies relating to the El Niño Southern Oscillation (ENSO), the Madden-Julian Oscillation, biomass burning events, and urban pollution (e.g., Ziemke et al., 2007, 2009; Chandra et al., 2009; Kar et al., 2010).

All of the methods used for deriving global maps of TCO and SCO have their individual strengths and weaknesses. Although the OMI/MLS residual methods of Ziemke et al. (2006) and Schoeberl et al. (2007) derive total column products of tropospheric ozone, TES provides additional profile information of ozone varying about 1-2 measurement degrees of freedom for the troposphere, albeit only at nadir along orbital track (e.g., Figs. 1-2 of Zhang et al., 2010). The optimization method of Liu et al. (2010) yields tropospheric degrees of freedom closer to one (e.g., Figs. 3-4 of Liu et al., 2010) which is somewhat less than TES but with much greater horizontal coverage compared to TES. The Stajner et al. (2008) and Doughty et al. (2011) studies both used Aura data assimilation (denoted ASM) and have shown very good results in simulating daily 3-D maps of tropospheric ozone profiles. The tropospheric component of the ASM invokes the Harvard GEOS-Chem model for simulating ozone in the troposphere. An advantage with the ASM model assimilation is generation of synoptic ozone profile information in the troposphere, but one disadvantage is that applications have been generally limited to short case studies including field campaigns such as INTEX-B. An underlying difficulty is that the GEOS-Chem tropospheric component of the ASM requires emissions inventories which take sub- stantial time and effort to implement correctly. Developing a long record from ASM for deriving climatology or for studying inter-annual or perhaps decadal variability requires much more effort than for short records. Ozone derived from data assimilation and satellite retrieval methods tend to fill two different needs, generally that of providing profile information and long data records, respectively.

The objective of this study is to develop a six-year global climatology of TCO and SCO from Aura OMI and MLS measurements. The climatology is useful as a benchmark test of basic seasonal-cycle and seasonal spatial variability present in photochemistry-transport and free-running global circulation models of the ocean-atmosphere. The climatology is also potentially useful as a priori information for ozone retrieval algorithms. It is noted that Martin et al. (2007) included an earlier version of OMI/MLS monthly mean TCO and derived an optimal assessment of global tropospheric nitrogen in the Goddard Earth Observing System Chemistrytransport model (GEOS-Chem) which was consistent with both the OMI/MLS ozone and the generated modeled ozone. In other words, by varying nitrogen in the model it was possible to yield consistent TCO between measurement and model, thus improving confidence in the assessed modeled nitrogen.

In the following, Sect. 2 discusses the OMI and MLS satellite measurements, Sect. 3 compares the TCO with ozonesondes, section 4 compares the TCO with the Labow Logan McPeters (LLM) ozone climatology, Sects. 5-6 discuss properties of the derived TCO and SCO climatologies, and finally Sect. 7 is a summary.

\section{Aura OMI and MLS Ozone measurements}

OMI and MLS are two out of a total of four instruments onboard the Aura spacecraft which is flown in a sunsynchronous polar orbit at $705 \mathrm{~km}$ altitude with a $98.2^{\circ}$ inclination. Aura was launched in July 2004 and has been providing measurements since August 2004 to the present. The spacecraft has an equatorial crossing time of 01:45 p.m. (ascending node) with about 98.8 min per orbit (14.6 orbits per day on average). Schoeberl et al. (2006) provide an overview of the EOS Aura mission and discuss the various measurements from the four Aura instruments.

OMI is a nadir-scanner which at visible $(350-500 \mathrm{~nm})$ and UV wavelength channels (UV-1: 270-314 nm; UV-2: 306$380 \mathrm{~nm}$ ) detects backscattered solar radiance to measure column ozone with near global coverage (aside from polar night latitudes) over the Earth with a resolution of $13 \mathrm{~km} \times 24 \mathrm{~km}$ at absolute nadir. Aside from ozone, OMI also measures Optical Centroid Cloud Pressure (OCCP), aerosols, $\mathrm{NO}_{2}, \mathrm{SO}_{2}$, $\mathrm{HCHO}$, and several other trace gases in the troposphere and stratosphere (Levelt et al., 2006). Measurements of ozone from OMI are determined using the OMTO3 v8.5 algorithm which is an extension of the TOMS v8 algorithm. A 

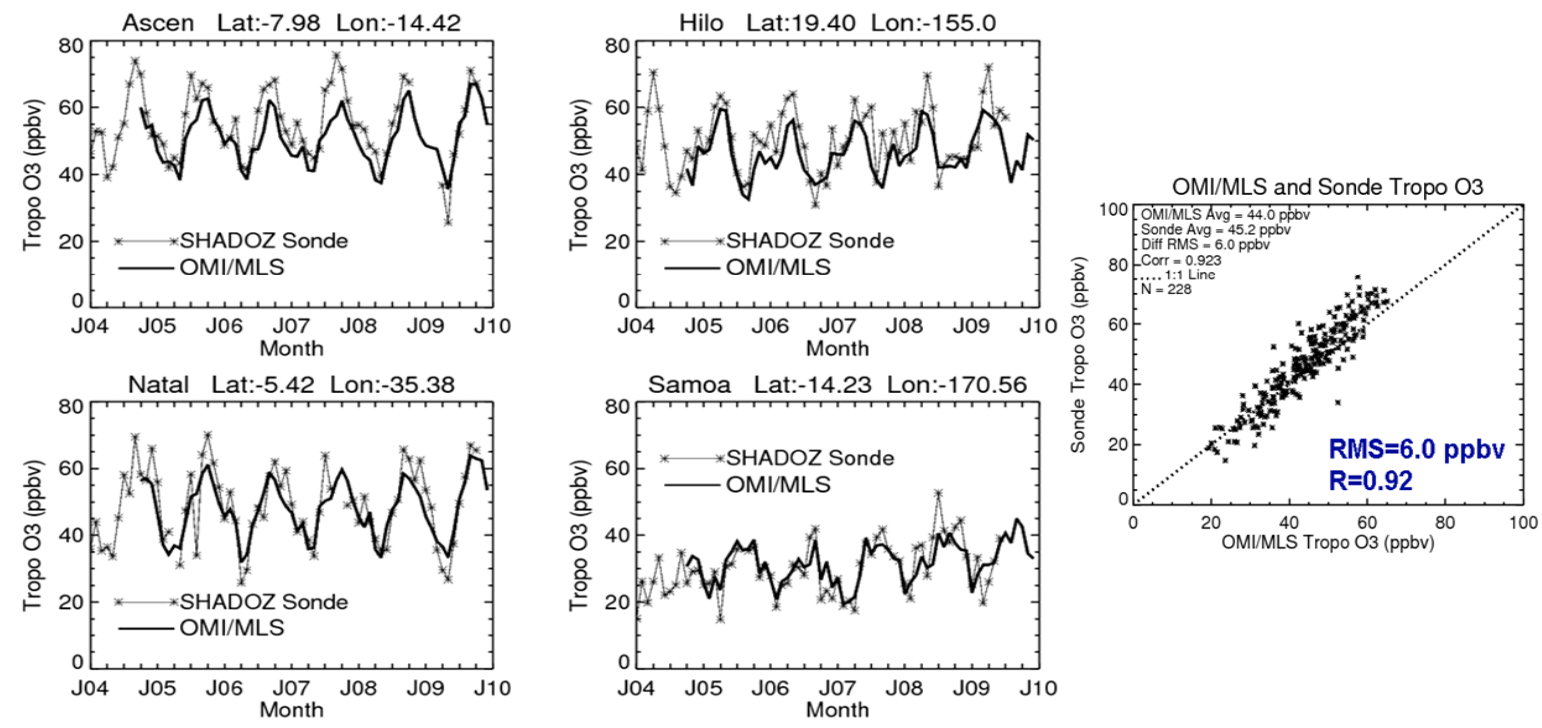

Fig. 1. Comparison time series of tropospheric ozone mean volume mixing ratio (in ppbv) between OMI/MLS (dark curves) and several selected common station measurements from SHADOZ (light curves). Also included at far right is a 1-1 comparison scatter plot for the measurements.
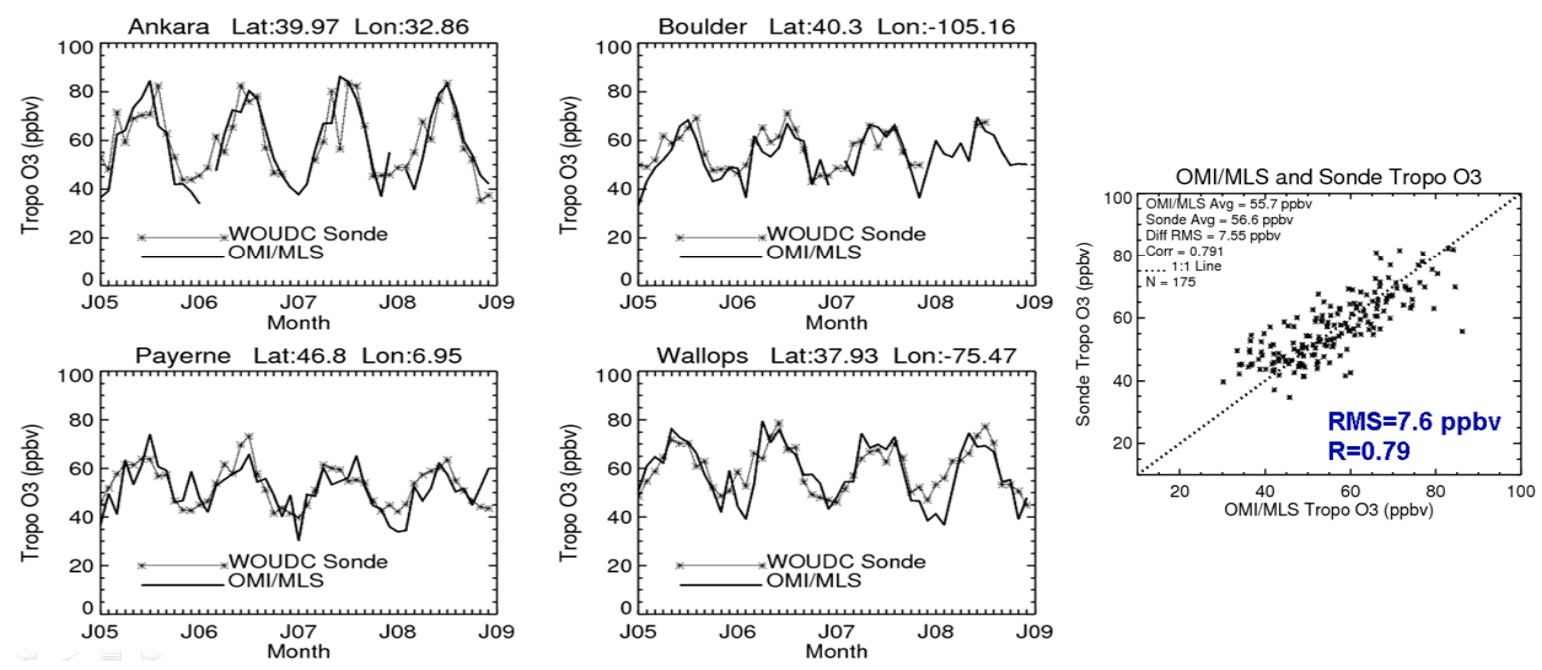

Fig. 2. Similar to Fig. 1 but for selected extra-tropical WOUDC ozonesonde stations.

description of the TOMS v8 algorithm may be obtained from the TOMS V8 CD DVD, or from the OMI Algorithm Theoretical Basis Document (ATBD) from the web page http: //toms.gsfc.nasa.gov/version8/v8toms_atbd.pdf. One main difference between the TOMS v8 and the OMTO3 v8.5 algorithms is the treatment of clouds. The TOMS $v 8$ and earlier versions of OMTO3 use a cloud pressure climatology based on thermal infrared cloud-top pressures, whereas OMTO3 v8.5 uses OCCP derived with OMI by the rotational Raman scattering method. The use of simultaneously measured OCCP significantly improves estimates of total column ozone, especially in the presence of bright clouds (Joiner and Vasilkov, 2006).
The MLS instrument is a thermal-emission microwave limb sounder that measures vertical profiles of mesospheric, stratospheric, and upper tropospheric temperature, ozone, and several other important constituents such as $\mathrm{CO}$ and $\mathrm{H}_{2} \mathrm{O}$ from limb scans taken in the direction ahead of the Aura satellite orbital track. The MLS profile measurements are made about 7 min before OMI views the same location during ascending (daytime) orbital tracks. These we refer to as "co-located" measurements between OMI and MLS. MLS also measures ozone and other atmospheric constituents for descending nighttime orbits which on a given day can be up to $\pm 12 \mathrm{~h}$ different in time from OMI daytime measurements. With combined ascending and descending nodes MLS makes 

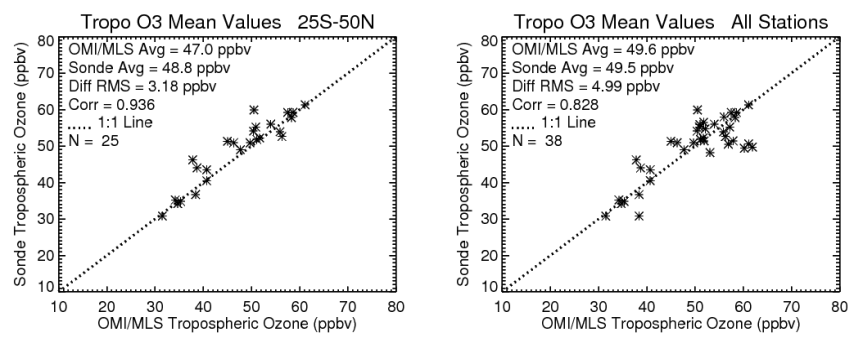

Fig. 3. (Left) Scatter plots of ozonesonde versus OMI/MLS mean tropospheric ozone for ozonesonde station locations lying between $25^{\circ} \mathrm{S}$ and $50^{\circ} \mathrm{N}$. (Right) Same as left panel, except for all ozonesonde stations from $90^{\circ} \mathrm{S}$ to $90^{\circ} \mathrm{N}$. The values plotted are time series averages in units ppbv.

around 3500 vertical profile measurements over the Earth per day. This study includes only the ascending orbit colocated data from MLS for deriving SCO. Details regarding the instrument including spectrometers, spectral channels, calibration, and other topics are discussed by Waters et al. (2006) and in related papers in the same journal. We have used version 3.3 ozone profile measurements from MLS to calculate global fields of SCO for the OMI/MLS residual method. Information regarding the MLS v3.3 ozone measurements including a data quality description document is available online from the NASA Data and Information Services Center webpage (http://disc.sci.gsfc.nasa. gov/gesNews/mls_new_data_version_release). Froidevaux et al. (2008) provides discussion and validation of the previous v2.2 measurements of MLS ozone and other trace gases. At the present time both $\mathrm{v} 2.2$ and $\mathrm{v} 3.3$ are provided to the science community. While v2.2 retrieval has 37 pressure levels, v3.3 retrieval has 55 pressure levels but it exhibits an oscillatory signature (particularly in the tropical upper troposphere/lower stratosphere) resulting in more outliers and missing data than with v2.2. The oscillatory behavior of the profile retrieval with $v 3.3$ impacts less the calculation of the stratospheric column amounts. Our analysis of SCO from MLS shows that there is little difference between using v2.2 or v3.3 other than a small systematic offset (v3.3 minus v2.2) at all latitudes of about $+2.5 \mathrm{DU}$. As was similarly done by Ziemke et al. (2006), MLS v3.3 SCO was adjusted to CCD SCO from OMI by subtracting this offset from MLS SCO.

For the OMI/MLS residual method SCO is determined from vertically integrated MLS ozone profiles which is subtracted from OMI total column ozone to derive TCO. Tropopause pressure, which separates tropospheric from stratospheric column ozone comes from National Centers for Environmental Prediction (NCEP) using the World Meteorological Organization (WMO) $2 \mathrm{~K} \mathrm{~km}^{-1}$ lapse rate tropopause definition. SCO from MLS is determined by pressure integration of ozone volume mixing ratio profiles from $0.0215 \mathrm{hPa}$ down to the NCEP tropopause. The MLS ozone profile measurements were linearly in-
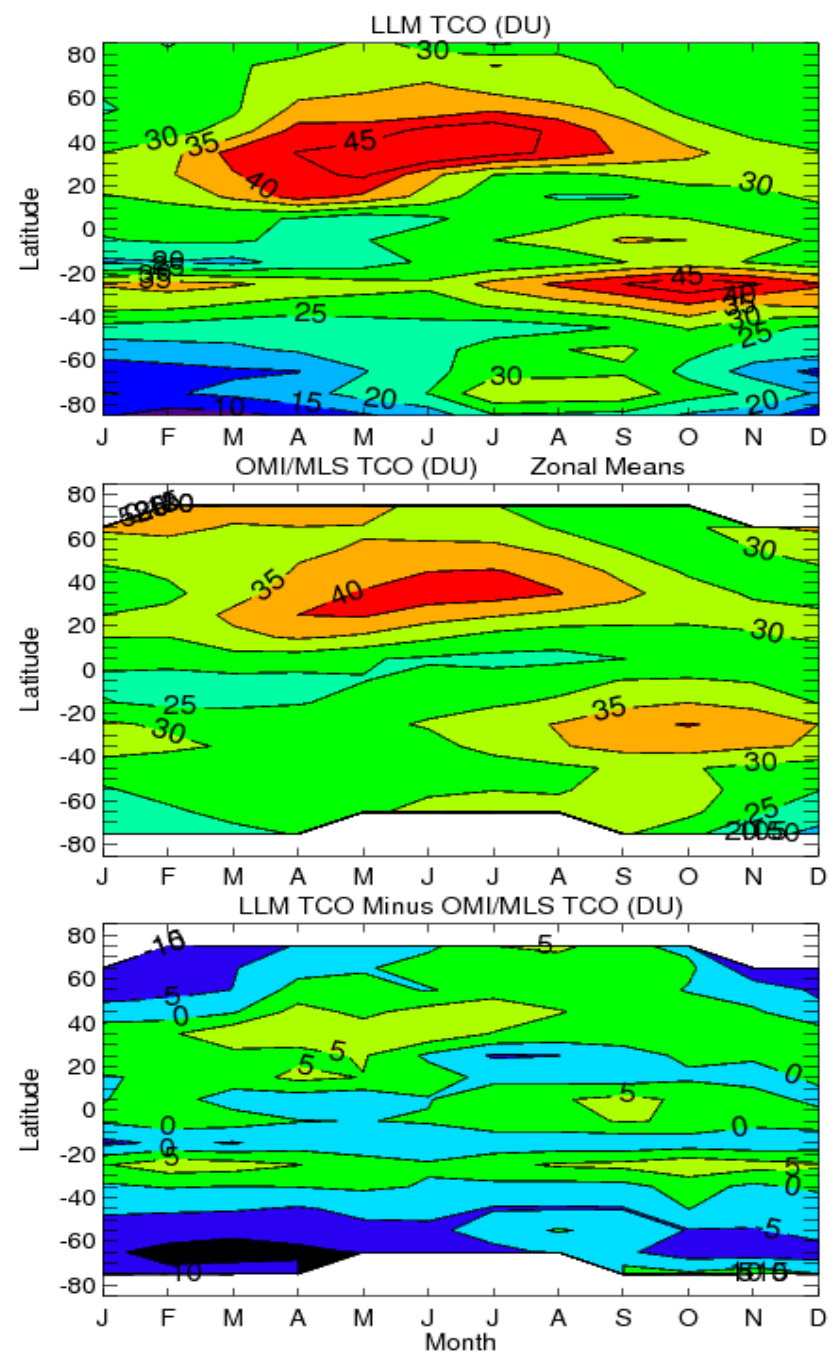

Fig. 4. (Top) Labow-Logan_McPeters (LLM) tropospheric column ozone climatology. (middle) OMI/MLS tropospheric column ozone climatology. (Bottom) LLM minus OMI/MLS climatology difference. All measurements are in Dobson Units. The colors in the panels going from blue/black to red represent smallest to largest (or most positive) values, respectively.

terpolated in log-pressure to the NCEP tropopause pressure to derive SCO. MLS SCO (in Dobson Units, DU; $1 \mathrm{DU}=2.69 \times 10^{20}$ molecules $\mathrm{m}^{-2}$ ) was determined by standard log-pressure integration of ozone partial pressure:

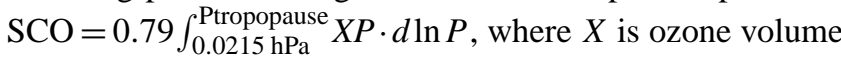
mixing ratio in units parts per million by volume (ppmv) and $P$ is pressure in units $\mathrm{hPa}$. The recommended range for scientific analysis of MLS v3.3 ozone profiles is 0.0215 $261 \mathrm{hPa}$. As was done by Ziemke et al. (2006), nearly global SCO from MLS for each day was achieved by including ozone retrievals down to $316 \mathrm{hPa}$. The uncertainty in derived SCO from MLS by including the $316 \mathrm{hPa}$ level beyond $261 \mathrm{hPa}$ can be estimated. Documentation for MLS 
v3.3 ozone measurements suggests root-mean square (RMS) uncertainties of about $0.03 \mathrm{ppmv}$ at $261 \mathrm{hPa}$ and $0.05 \mathrm{ppmv}$ at $316 \mathrm{hPa}$. Using the above integration formula, an upperbound estimate of the RMS uncertainty in $261-316 \mathrm{hPa}$ column ozone from MLS is then about 3.5 DU.

MLS SCO data were initially binned to $1^{\circ}$ latitude $\times 1.25^{\circ}$ longitude to be compatible with OMI level3 (L3) gridded total column ozone. Tropopause pressures from NCEP analyses were interpolated to this same resolution from a coarser $2.5^{\circ} \times 2.5^{\circ}$ gridding. It is noted for MLS limb measurements that the horizontal optical path is about $300 \mathrm{~km}$ which is larger than the horizontal size of OMI L3 gridded data, but is comparable to the size of original NCEP gridded measurements. To derive a high density SCO field we have used the two-step spatial interpolation of Ziemke et al. (2006). The interpolation for SCO includes first a moving 2-D (latitude/longitude) Gaussian window along daytime orbit to fill in intermittent gaps along-track for MLS SCO, followed by a linear interpolation along longitude between MLS SCO data. This interpolation approach preserves the along-track measurements of SCO from MLS at all latitudes. Following derivation of daily maps of SCO and TCO at $1^{\circ} \times 1.25^{\circ}$ resolution, the data were averaged monthly in $5^{\circ} \times 5^{\circ}$ and $10^{\circ} \times 10^{\circ}$ bins. We have evaluated OMI and MLS ozone data for the time period 1 October 2004-31 December 2010 which represents approximately six years of continuous measurements. The TCO and SCO monthly climatology fields were smoothed along longitude using Fourier analysis by retaining zonal wave numbers $0-12$ which both reduces noise and ensures periodic continuation across the dateline.

\section{Comparisons of OMI/MLS tropospheric ozone with ozonesondes}

Validation of OMI/MLS TCO is based upon Southern Hemisphere Additional OZonseondes (SHADOZ) (Thompson et al., 2003) and World Ozone and Ultraviolet radiation Data Center (WOUDC) (Fioletov, et al., 2008) ozonesonde measurements whereby monthly means from OMI/MLS are compared with monthly ensemble averages from the ozonesondes. The ozonesonde monthly ensemble data represent for each station an average of all existing ozonesonde measurements in a given month (which could vary from one to several). OMI/MLS TCO was converted to ozone mean volume mixing ratio and then compared with mean volume mixing ratio for both the SHADOZ and WOUDC ozonesondes. Ozone mean volume mixing ratio for the tropical SHADOZ stations involved pressure averaging of ozone for ground-to- $120 \mathrm{hPa}$ while for extra-tropical WOUDC stations this was ground-to- $350 \mathrm{hPa}$. The ozonesonde data for our comparisons extend for years 2004-2009 for SHADOZ and 2005-2008 for WOUDC. Of the several SHADOZ and WOUDC stations processed, 38 of them had measurements that overlapped with the OMI/MLS time period.
Figures 1 and 2 show tropospheric ozone time series comparisons for several stations from SHADOZ and WOUDC, respectively. Also included in these figures are one-to-one scatter diagrams of the combined data. The stations in Figs. 1 and 2 were chosen not just because these are common stations but also because of nearly complete monthto-month temporal coverage with large peak-to-peak annualcycle changes of $\sim 20-30$ parts per billion by volume (ppbv). Although seasonal cycles including mean values at each station seem to compare well in the time series of both figures there appears to be systematic differences between sonde and satellite ozone. In Fig. 1 the largest time series values from the ozonesondes are consistently larger than satellite by at least $\sim 5$ ppbv on average except for Samoa in the tropical Pacific; this yields a slope slightly exceeding that of the oneto-one line in the scatter diagram. The ozone annual cycles for the extra-tropical stations in Fig. 2 are larger than in the tropics but there is also more scatter in the one-to-one comparisons.

There are important issues involved when comparing ozonesondes with satellite-retrieved tropospheric ozone. The ozonesondes represent wind-advected measurements along trajectory paths and are very different than satellite measurements which provide ozone averages over broad regions. Also, ozone in the troposphere (such as shown by Avery et al., 2010) can exhibit changes of 30-50 ppbv over horizontal distances of only a few $\mathrm{km}$ or less. With such large spatial variability the most one can gain in comparing satellite measured ozone versus ozonesondes is to evaluate seasonal cycles and climatological means, and extreme variability such as inter-annual changes in the tropical Pacific caused by ENSO events. Table 1 provides a list of comparisons between OMI/MLS and the SHADOZ/WOUDC ozonesondes with station latitudes arranged from northern-most at top to southern-most at bottom. Listed for each station is the total number of monthly ensemble profile measurements, mean values for OMI/MLS and ozonesondes, and RMS of their differences. For most of the stations listed in Table 1 the RMS values lie between $4 \mathrm{ppbv}$ and $10 \mathrm{ppbv}$. For stations northward of $50^{\circ} \mathrm{N}, \mathrm{RMS}$ is greater than $10 \mathrm{ppbv}$ except for Debilt and Valentia. The larger RMS numbers in NH high latitudes are partly explained by the sparse nature of monthly measurements from both OMI/MLS and ozonesondes. Smit et al. (2007) provide a detailed analysis of the ECC ozonesonde instruments and measurement errors. There are several contributing factors for ozonesonde errors including mechanical and chemical, from pumping efficiency to KI concentration and basic operation of instruments. Smit et al. (2007) concluded that with standardized operating procedures the ECC ozonesondes should have an accuracy of $5-10 \%$ and precision of 3-5\% from ground to $30 \mathrm{~km}$ altitude. It is possible that there are ozonesonde error issues involved in Table 1 regarding the larger RMS differences, but also possibly yet unresolved errors in OMI satellite measurements as well, in particular the higher latitude station locations associated with 
Table 1. Statistical comparisons between OMI/MLS and SHADOZ/WOUDC sonde tropospheric mean volume mixing ratio (in ppbv) with the station latitudes arranged from northern-most at top to southern-most at bottom. Included for each station is the total number of monthly ensemble profile measurements for the ozonesondes (first column), mean values for OMI/MLS and ozonesondes (second and third columns), and RMS of their differences (fourth column).

\begin{tabular}{|c|c|c|c|c|}
\hline Station & $\mathrm{N}$ & OMI/MLS & Sonde & Diff RMS \\
\hline $\operatorname{Alert}\left(82.5^{\circ} \mathrm{N}, 62.3^{\circ} \mathrm{W}\right)$ & 27 & 60.2 & 49.4 & 19.4 \\
\hline Eureka $\left(80.0^{\circ} \mathrm{N}, 85.9^{\circ} \mathrm{W}\right)$ & 22 & 56.9 & 50.5 & 13.3 \\
\hline Resolute $\left(74.7^{\circ} \mathrm{N}, 95.0^{\circ} \mathrm{W}\right)$ & 33 & 61.9 & 49.7 & 19.1 \\
\hline $\operatorname{Lerwick}\left(60.1^{\circ} \mathrm{N}, 1.2^{\circ} \mathrm{W}\right)$ & 46 & 57.2 & 55.2 & 10.7 \\
\hline Churchill $\left(58.7^{\circ} \mathrm{N}, 94.1^{\circ} \mathrm{W}\right)$ & 36 & 61.1 & 50.6 & 14.3 \\
\hline Stonyplain $\left(53.6^{\circ} \mathrm{N}, 114.1^{\circ} \mathrm{W}\right)$ & 45 & 53.1 & 48.2 & 11.0 \\
\hline $\operatorname{Goosebay}\left(53.3^{\circ} \mathrm{N}, 60.4^{\circ} \mathrm{W}\right)$ & 38 & 57.9 & 51.4 & 13.2 \\
\hline Legionwo $\left(52.4^{\circ} \mathrm{N}, 21.0^{\circ} \mathrm{E}\right)$ & 39 & 51.8 & 56.5 & 12.1 \\
\hline Lindenberg $\left(52.2^{\circ} \mathrm{N}, 14.1^{\circ} \mathrm{E}\right)$ & 48 & 51.0 & 55.9 & 11.1 \\
\hline $\operatorname{Debilt}\left(52.1^{\circ} \mathrm{N}, 5.2^{\circ} \mathrm{E}\right)$ & 45 & 52.1 & 54.7 & 8.4 \\
\hline Valentia $\left(51.9^{\circ} \mathrm{N}, 10.3^{\circ} \mathrm{W}\right)$ & 27 & 56.0 & 58.0 & 9.4 \\
\hline Brattslake $\left(50.2^{\circ} \mathrm{N}, 104.7^{\circ} \mathrm{W}\right)$ & 46 & 51.9 & 51.4 & 12.3 \\
\hline $\operatorname{Praha}\left(50.0^{\circ} \mathrm{N}, 14.5^{\circ} \mathrm{E}\right)$ & 12 & 50.4 & 54.1 & 7.9 \\
\hline Kelowna $\left(49.9^{\circ} \mathrm{N}, 119.4^{\circ} \mathrm{W}\right)$ & 36 & 51.1 & 51.8 & 12.4 \\
\hline Payerne $\left(46.8^{\circ} \mathrm{N}, 7.0^{\circ} \mathrm{E}\right)$ & 48 & 51.7 & 52.2 & 6.6 \\
\hline $\operatorname{Egbert}\left(44.2^{\circ} \mathrm{N}, 79.8^{\circ} \mathrm{W}\right)$ & 41 & 58.3 & 57.8 & 9.3 \\
\hline $\operatorname{Barajas}\left(40.5^{\circ} \mathrm{N}, 3.6^{\circ} \mathrm{W}\right)$ & 47 & 55.9 & 53.9 & 7.0 \\
\hline Boulder $\left(40.3^{\circ} \mathrm{N}, 105.2^{\circ} \mathrm{W}\right)$ & 36 & 54.0 & 56.0 & 6.6 \\
\hline $\operatorname{Ankara}\left(40.0^{\circ} \mathrm{N}, 32.9^{\circ} \mathrm{E}\right)$ & 43 & 57.5 & 59.2 & 9.9 \\
\hline Wallops $\left(37.9^{\circ} \mathrm{N}, 75.5^{\circ} \mathrm{W}\right)$ & 48 & 58.6 & 59.2 & 6.9 \\
\hline Huntsville $\left(34.7^{\circ} \mathrm{N}, 86.6^{\circ} \mathrm{W}\right)$ & 36 & 56.3 & 52.6 & 12.4 \\
\hline $\operatorname{Isfahan}\left(32.5^{\circ} \mathrm{N}, 51.7^{\circ} \mathrm{E}\right)$ & 29 & 61.1 & 61.3 & 11.5 \\
\hline Hongkong $\left(22.3^{\circ} \mathrm{N}, 114.2^{\circ} \mathrm{E}\right)$ & 47 & 49.7 & 50.9 & 7.8 \\
\hline $\operatorname{Hilo}\left(19.4^{\circ} \mathrm{N}, 155.0^{\circ} \mathrm{W}\right)$ & 58 & 46.3 & 50.9 & 6.8 \\
\hline Alajuela $\left(10.0^{\circ} \mathrm{N}, 84.2^{\circ} \mathrm{W}\right)$ & 27 & 40.7 & 40.5 & 4.2 \\
\hline Heredia $\left(10.0^{\circ} \mathrm{N}, 84.1^{\circ} \mathrm{W}\right)$ & 16 & 40.7 & 43.5 & 5.9 \\
\hline $\operatorname{Panama}\left(7.8^{\circ} \mathrm{N}, 80.3^{\circ} \mathrm{W}\right)$ & 2 & 38.7 & 44.0 & 6.5 \\
\hline $\operatorname{Kuala}\left(2.7^{\circ} \mathrm{N}, 101.7^{\circ} \mathrm{E}\right)$ & 51 & 34.2 & 35.2 & 5.6 \\
\hline $\operatorname{Sancr}\left(0.9^{\circ} \mathrm{S}, 89.6^{\circ} \mathrm{W}\right)$ & 31 & 38.4 & 36.7 & 5.0 \\
\hline Nairobi $\left(1.3^{\circ} \mathrm{S}, 36.8^{\circ} \mathrm{E}\right)$ & 52 & 37.8 & 46.2 & 9.9 \\
\hline Malindi $\left(3.0^{\circ} \mathrm{S}, 40.2^{\circ} \mathrm{E}\right)$ & 13 & 45.0 & 51.3 & 7.6 \\
\hline $\operatorname{Natal}\left(5.4^{\circ} \mathrm{S}, 35.4^{\circ} \mathrm{W}\right)$ & 58 & 47.7 & 49.0 & 6.0 \\
\hline $\operatorname{Java}\left(7.5^{\circ} \mathrm{S}, 112.6^{\circ} \mathrm{E}\right)$ & 44 & 35.3 & 34.8 & 6.7 \\
\hline $\operatorname{Ascen}\left(8.0^{\circ} \mathrm{S}, 14.4^{\circ} \mathrm{W}\right)$ & 56 & 50.9 & 55.2 & 6.7 \\
\hline $\operatorname{Samoa}\left(14.2^{\circ} \mathrm{S}, 170.6^{\circ} \mathrm{W}\right)$ & 56 & 31.5 & 30.8 & 4.5 \\
\hline $\operatorname{Fiji}\left(18.1^{\circ} \mathrm{S}, 178.4^{\circ} \mathrm{E}\right)$ & 22 & 34.7 & 34.2 & 4.7 \\
\hline $\operatorname{Reunion}\left(21.0^{\circ} \mathrm{S}, 55.5^{\circ} \mathrm{E}\right)$ & 52 & 50.5 & 59.9 & 11.7 \\
\hline Neumayer $\left(70.7^{\circ} \mathrm{S}, 8.3^{\circ} \mathrm{W}\right)$ & 26 & 38.4 & 30.8 & 17.7 \\
\hline
\end{tabular}

high solar zenith angles. Figure 3 compares climatological means for OMI/MLS and ozonesondes. The left panel in Fig. 3 includes station latitudes $25^{\circ} \mathrm{S}-50^{\circ} \mathrm{N}$ and the right panel includes all stations listed in Table 1. It is apparent that the one-to-one scatter comparison becomes worse when high latitude stations are included.

\section{Comparisons of OMI/MLS and LLM tropospheric ozone climatology}

Logan (1999) provided an extensive analysis of global ozone based upon ozonesonde measurements. More recently McPeters et al. (2007) expanded the ozonesonde evaluation of Logan (1999) and derived a global zonal mean climatology of total atmospheric ozone as a function of latitude, altitude, and month of year. This climatology was determined by combining ozonesondes with satellite ozone measurements from SAGE and MLS. The final climatology product 
is referred to as the Labow-Logan-McPeters (LLM) climatology and is currently used in the OMTO3 v8.5 algorithm processing for both OMI and TOMS ozone retrievals.

Figure 4 shows a comparison of LLM TCO climatology (top panel) with OMI/MLS TCO climatology (middle panel) and their difference (bottom panel). The characteristics are generally consistent between the datasets including a seasonal transition in peak $\mathrm{TCO}$ in the $\mathrm{NH}$ from the tropics to mid-latitudes when going from spring to summer months. LLM minus OMI/MLS TCO difference (bottom panel) is up to $+5 \mathrm{DU}$ for some months in the latitude range $40^{\circ} \mathrm{S}$ to $40^{\circ} \mathrm{N}$. These differences may be explained as a data sampling issue as the LLM climatology is determined from TCO measurements over land whereas TCO from OMI/MLS in Fig. 4 is averaged along all longitudes and includes low ozone regions not sampled by ozonesondes. In the high latitudes in Fig. 4 offset differences are instead negative which exceed $-5 \mathrm{DU}$ in both hemispheres. These negative differences in high latitudes are not resolved but may relate to ozonesonde errors or sampling and/or errors in tropospheric ozone measured by OMI/MLS residual at these high solar zenith angle conditions.

\section{OMI/MLS global TCO climatology maps}

As noted in the Introduction, tropospheric ozone determined from TOMS/SAGE residual (Fishman et al., 1990) was limited both temporally and spatially because of sparse SAGE measurements. An improvement was made for the SAGE sampling problem by Fishman et al. (2003) by using instead NOAA SBUV to derive SCO, however there is little ozone profile information obtained from SBUV below the ozone number density peak (i.e., atmospheric pressures greater than $\sim 30-40 \mathrm{hPa}$ ). To alleviate this SBUV ozone profile problem Fishman et al. (2003) applied an empirical correction to SBUV ozone profiles to improve the SCO fields.

A six-year TCO climatology from OMI and MLS ozone is shown in Fig. 5a-c for each of the months JanuaryDecember. TCO at high latitudes in Fig. 5 is flagged as missing data involving polar night latitudes (i.e., where there are no OMI measurements) and additional subjective data flagging. Subjective data flagging included OMI scenes with solar zenith angles greater than $82^{\circ}$ or questionable derived TCO product values at high latitudes.

The main features of the TCO climatology in Fig. 5 are briefly summarized. At tropical latitudes TCO for each month is characterized by low amounts in the Pacific $\sim 15-$ $25 \mathrm{DU}$ with much higher columns $\sim 35-45 \mathrm{DU}$ in the Atlantic. Lowest TCO in the tropics lies in the western Pacific during July-September with values $15-20$ DU. The low columns in the tropical Pacific are largely a manifestation of deep convection and vertical injection of low marine boundary layer/low tropospheric ozone into the middle and upper troposphere. Largest TCO in the Southern
Hemisphere occurs during September-October in the tropical south Atlantic with values of 40-45 DU. These high values are associated with changes in planetary-scale transport of ozone rich air masses and ozone production sources which include varying effects from lightning, biomass burning, soil emissions, and fossil fuels. Sauvage et al. (2007) infers from GEOS Chem model simulations that the dominant source of ozone in the tropical south Atlantic is lightning. Outside the tropics, smallest TCO (less then $25 \mathrm{DU}$ ) lies in the Southern Hemisphere high latitudes during winter. The largest TCO outside the tropics lies in the Northern Hemisphere associated with topographically-driven spatial variability year-round and has several sources including stratosphere-troposphere exchange, lightning, biomass burning, and pollution from fossil fuel combustion. The largest columns occur during June-July in regions of the Mediterranean and the eastern Asia continent extending eastward over the Pacific.

We compare similarities and differences between the TCO climatology fields in Fig. 5 with previous investigations. There have been many studies based upon measuring tropospheric ozone from satellite instruments but only Fishman et al. (1990) and Fishman et al. (2003) have produced TCO climatology maps (based upon 1979-1987 and 19792003 data, respectively). Liu et al. (2006) also derived tropospheric ozone maps (from Global Ozone Monitoring Experiment (GOME)), but only for a short record from December 1996-November 1997. All of these retrievals of tropospheric ozone including our own OMI/MLS measurements have a persistent wave-one feature in the southern tropics which maximizes in September-November months, and also a summertime maximum in the northern extra-tropics. Comparisons between the tropospheric ozone fields in Fig. 5 with tropospheric ozone fields plotted in Fig. 9 of Fishman et al. (1990) from TOMS/SAGE residuals show similar general spatial patterns and seasonal cycles in most latitude ranges; however, one main difference is that the TOMS/SAGE tropospheric ozone summer maxima during June-August peaks at much higher northern latitudes $\left(\sim 50^{\circ} \mathrm{N}\right)$ than the OMI/MLS ozone which instead peaks around $40^{\circ} \mathrm{N}$. Comparison between the ozone fields in our Fig. 5 with the TOMS/SBUV ozone in Fig. 1 of Fishman et al. (2003) shows consistent spatial and temporal features, but the TOMS/SBUV residual does not indicate enhanced ozone in the Mediterranean region in June-August months as OMI/MLS does.

Figure 6 shows line plots of OMI/MLS tropospheric ozone climatology as a function of longitude for $30^{\circ}-40^{\circ} \mathrm{N}$ and $0^{\circ}-$ $10^{\circ} \mathrm{S}$. These latitude bands and months were chosen to show several large annually recurring features present in global TCO. The line plots in Fig. 6 also include $\pm 2 \sigma$ vertical bars for illustration where $\sigma$ is calculated as a six-year standard error of the mean. TCO in these two latitude bands has large spatial variability. The left panel shows zonal variability caused by a Mediterranean-Asian accumulation region (centered about $30^{\circ} \mathrm{E}$ ) and the mountains of the Tibetan Plateau 

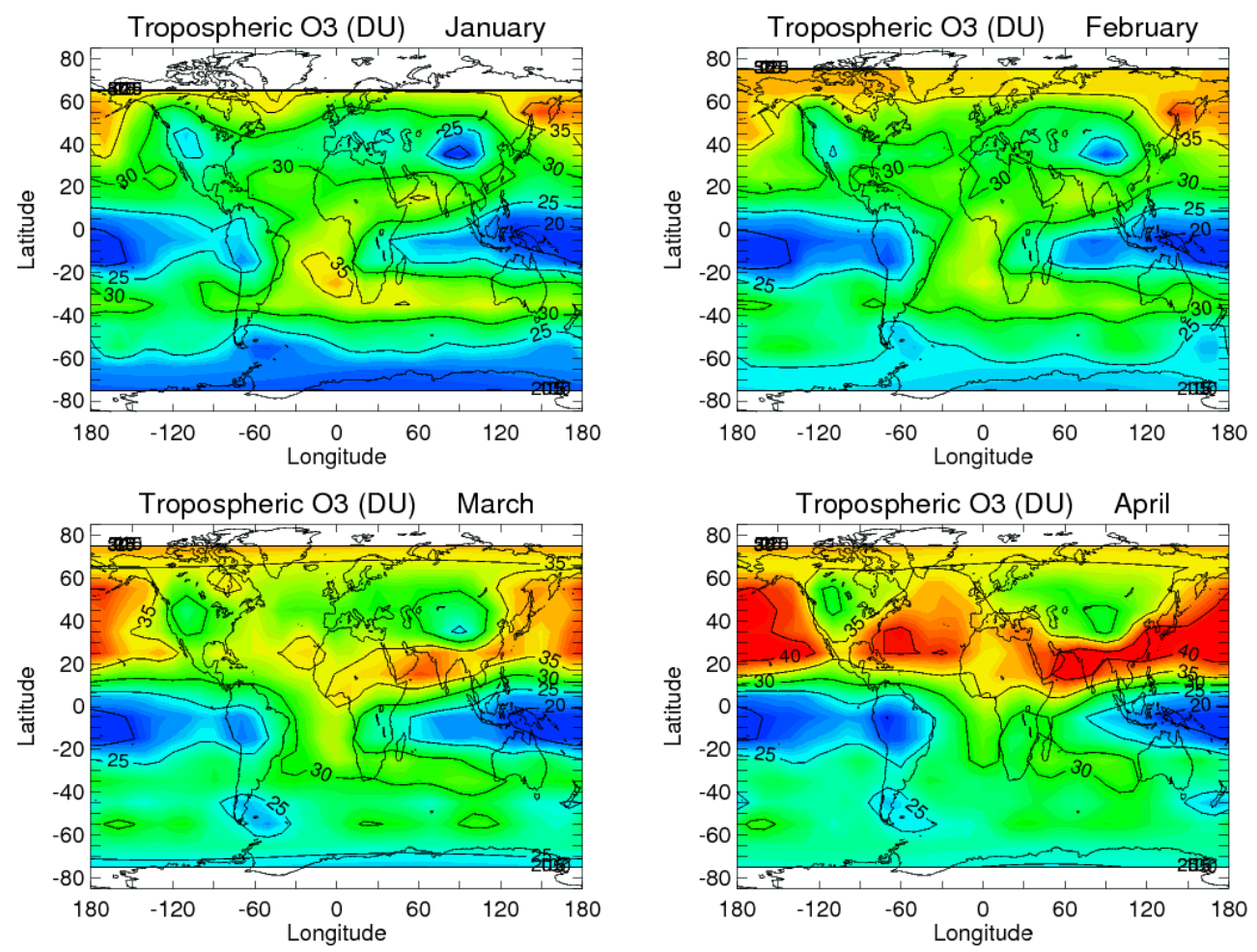

Fig. 5a. Tropospheric column ozone climatology (in Dobson Units) for months January-April from OMI/MLS residual ozone measurements. The colors in the panels going from blue to red represent smallest to largest values, respectively.
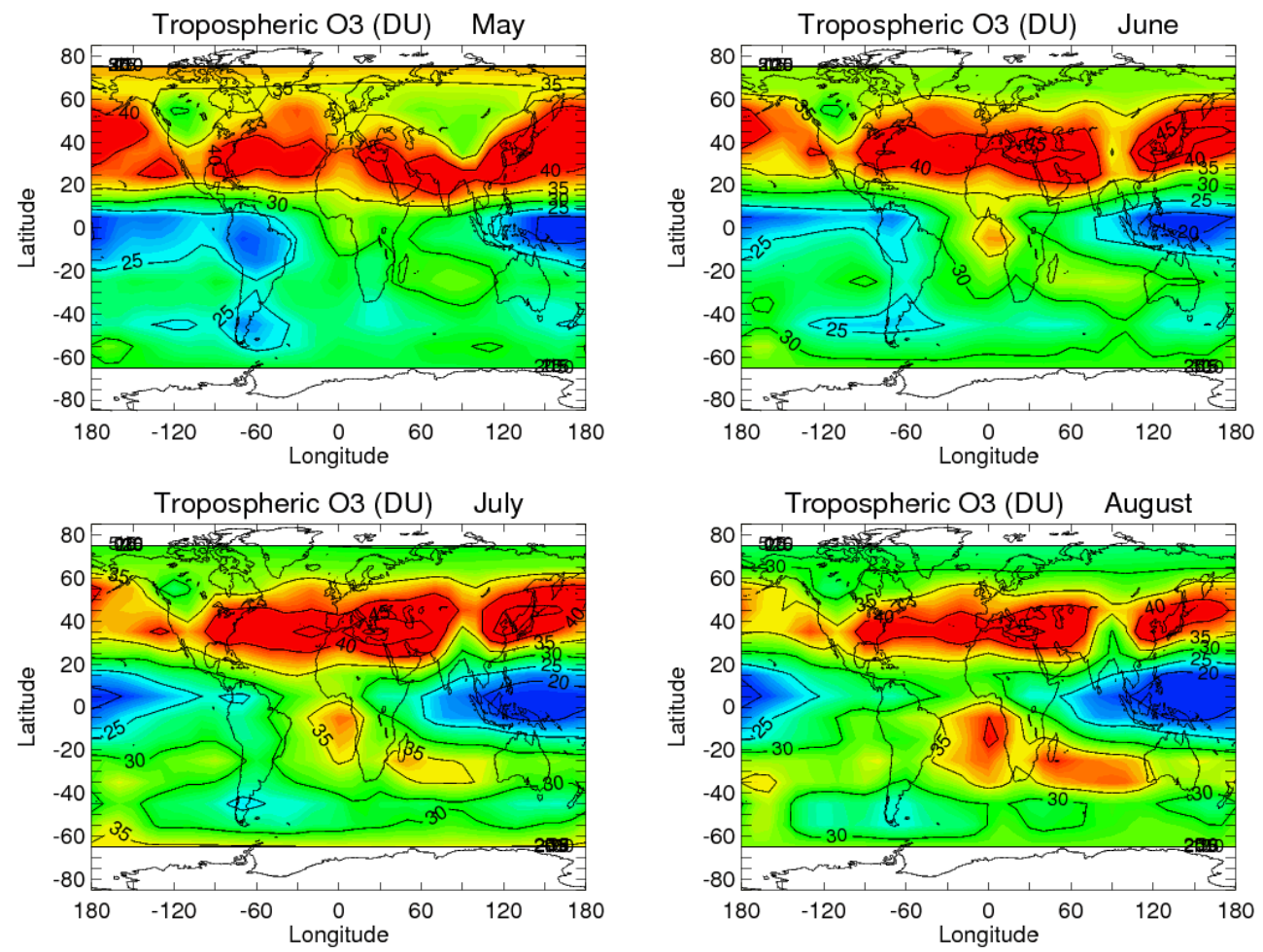

Fig. 5b. Same as Fig. 5a but for months May-August. 

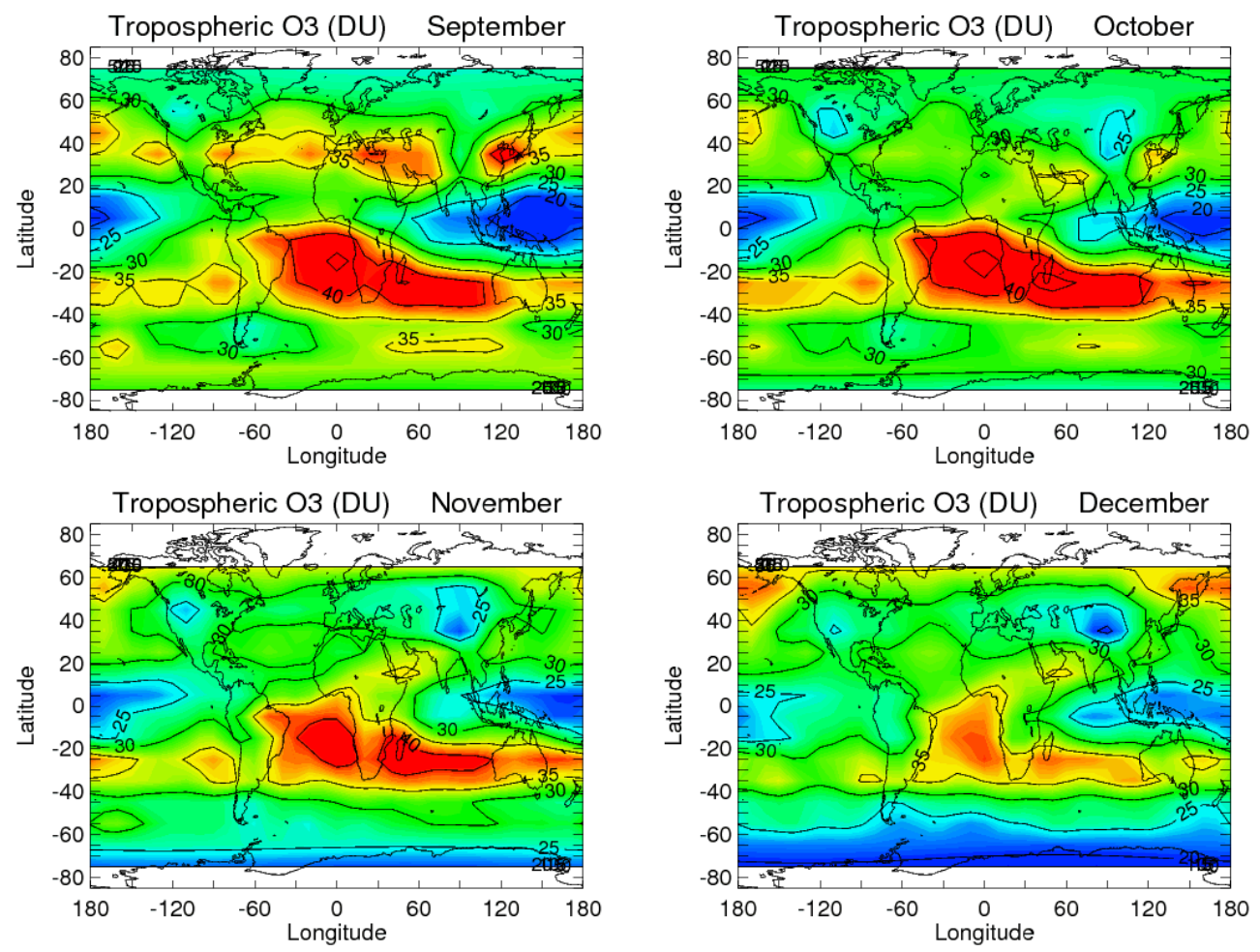

Fig. 5c. Same as Fig. $5 b$ but for months September-December.
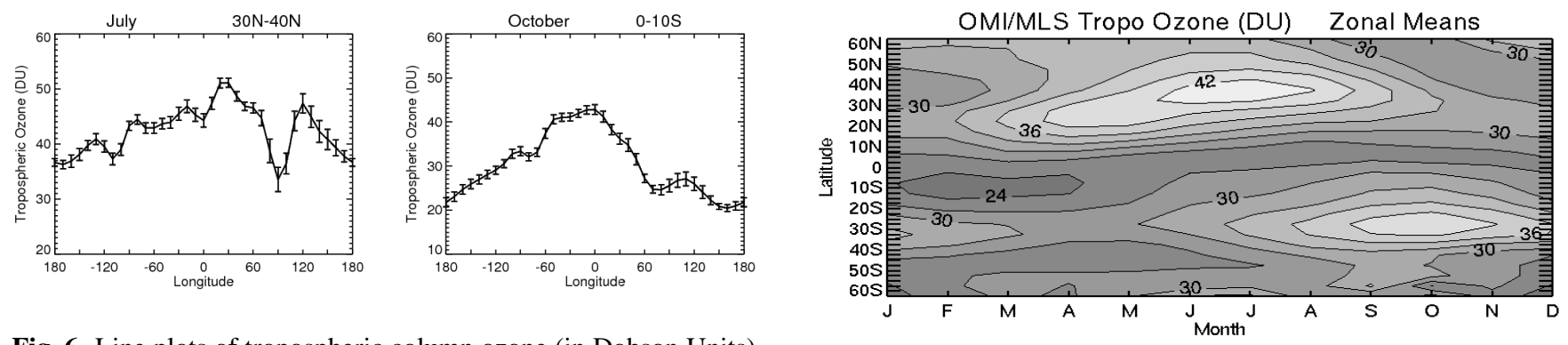

Fig. 6. Line plots of tropospheric column ozone (in Dobson Units) as a function of longitude for the latitude bands $30^{\circ}-40^{\circ} \mathrm{N}$ and $0^{\circ}-$ $10^{\circ} \mathrm{S}$. The plots include $\pm 2 \sigma$ vertical bars for illustration where $\sigma$ is the calculated six-year RMS standard error of the mean.

(centered about $90^{\circ} \mathrm{E}$ ). The right panel shows large contrast in TCO from low values in the tropical Pacific and high values in the tropical Atlantic (i.e., about $20 \mathrm{DU}$ versus $40 \mathrm{DU}$, respectively).

For applications such as evaluating 3-D chemistrytransport models of the atmosphere it is useful to derive a zonal mean climatology of TCO from OMI/MLS. A simple model comparison with zonal mean TCO climatology can reveal fundamental offsets or annual-cycle differences that can be used to aid in the development of models. Ziemke et al. (2006) compared an earlier version of zonal mean TCO between OMI/MLS and the Global Modeling Initiative (GMI) 3-D model and showed good agreement in latitude

Fig. 7. Zonal mean climatology of tropospheric column ozone (in Dobson Units) derived from October 2004-December 2010 $\mathrm{OMI} / \mathrm{MLS}$ at $5^{\circ}$ latitude resolution. The shading going from dark to light represents smallest to largest values, respectively.

gradients and temporal variability except for a 5-10 DU offset in the NH extending from the subtropics to mid-latitudes. It was surmised that errors in OMI from aerosols could be a contributing factor for the offset, but the primary indication was that the model was over-determining TCO by several DU in the $\mathrm{NH}$ subtropics/mid-latitudes in most months. Figure 7 shows the six-year climatology of zonal mean TCO. Lowest TCO occurs in the SH tropics around $10^{\circ} \mathrm{S}$ in JanuaryApril ( $<24 \mathrm{DU})$ and also in the $\mathrm{NH}$ and SH mid-latitudes in late fall to winter-spring ( $<30 \mathrm{DU})$. Largest TCO occurs in the NH mid-latitudes in June-July ( $>42$ DU) and in 
Table 2. Tropospheric column ozone zonal mean monthly mean climatology (in Dobson Units) from OMI/MLS at $5^{\circ}$ latitude resolution.

\begin{tabular}{|c|c|c|c|c|c|c|c|c|c|c|c|c|}
\hline Latitudes & Jan & Feb & Mar & Apr & May & Jun & Jul & Aug & Sep & Oct & Nov & Dec \\
\hline $60^{\circ} \mathrm{N}-65^{\circ} \mathrm{N}$ & 35.8 & 34.6 & 33.1 & 33.7 & 34.3 & 33.8 & 33.8 & 30.7 & 28.2 & 27.9 & 33.8 & 35.8 \\
\hline $55^{\circ} \mathrm{N}-60^{\circ} \mathrm{N}$ & 33.0 & 32.2 & 33.0 & 33.7 & 34.6 & 35.6 & 35.5 & 32.9 & 29.5 & 28.1 & 30.3 & 33.6 \\
\hline $50^{\circ} \mathrm{N}-55^{\circ} \mathrm{N}$ & 31.1 & 32.1 & 32.9 & 33.5 & 35.2 & 36.7 & 36.9 & 34.7 & 30.8 & 28.4 & 28.8 & 30.1 \\
\hline $45^{\circ} \mathrm{N}-50^{\circ} \mathrm{N}$ & 29.4 & 30.8 & 31.6 & 33.7 & 35.9 & 38.2 & 39.1 & 37.4 & 33.2 & 28.9 & 27.9 & 28.0 \\
\hline $40^{\circ} \mathrm{N}-45^{\circ} \mathrm{N}$ & 27.6 & 28.9 & 30.9 & 34.1 & 37.0 & 40.9 & 42.2 & 40.7 & 35.7 & 30.2 & 27.3 & 27.3 \\
\hline $35^{\circ} \mathrm{N}-40^{\circ} \mathrm{N}$ & 27.0 & 27.7 & 30.9 & 35.2 & 38.9 & 43.0 & 44.0 & 42.3 & 37.9 & 32.4 & 28.4 & 27.3 \\
\hline $30^{\circ} \mathrm{N}-35^{\circ} \mathrm{N}$ & 28.2 & 28.6 & 32.9 & 38.0 & 41.2 & 42.9 & 42.3 & 40.4 & 37.3 & 33.5 & 30.9 & 29.0 \\
\hline $25^{\circ} \mathrm{N}-30^{\circ} \mathrm{N}$ & 30.2 & 31.6 & 35.9 & 40.5 & 42.0 & 39.8 & 38.3 & 36.8 & 35.0 & 33.1 & 31.9 & 30.6 \\
\hline $20^{\circ} \mathrm{N}-25^{\circ} \mathrm{N}$ & 31.6 & 32.4 & 36.9 & 40.5 & 40.4 & 37.1 & 35.3 & 33.6 & 33.0 & 32.0 & 31.7 & 31.6 \\
\hline $15^{\circ} \mathrm{N}-20^{\circ} \mathrm{N}$ & 31.1 & 31.3 & 35.2 & 38.0 & 37.1 & 34.3 & 32.0 & 30.0 & 29.8 & 29.7 & 30.2 & 31.0 \\
\hline $10^{\circ} \mathrm{N}-15^{\circ} \mathrm{N}$ & 29.2 & 29.3 & 32.7 & 34.1 & 32.6 & 30.3 & 28.2 & 26.8 & 27.3 & 27.7 & 28.6 & 29.5 \\
\hline $5^{\circ} \mathrm{N}-10^{\circ} \mathrm{N}$ & 27.2 & 27.6 & 29.9 & 29.8 & 27.7 & 26.5 & 25.8 & 25.1 & 26.1 & 26.3 & 26.6 & 27.7 \\
\hline $0^{\circ}-5^{\circ} \mathrm{N}$ & 25.2 & 25.5 & 26.8 & 26.0 & 24.9 & 25.3 & 25.8 & 26.4 & 27.2 & 26.9 & 26.4 & 26.4 \\
\hline $0^{\circ}-5^{\circ} \mathrm{S}$ & 24.4 & 24.0 & 24.8 & 24.1 & 25.0 & 26.9 & 27.5 & 28.7 & 30.1 & 29.9 & 28.5 & 26.4 \\
\hline $5^{\circ} \mathrm{S}-10^{\circ} \mathrm{S}$ & 24.2 & 22.9 & 23.4 & 23.5 & 25.4 & 27.8 & 28.5 & 30.0 & 32.0 & 32.3 & 30.4 & 27.7 \\
\hline $10^{\circ} \mathrm{S}-15^{\circ} \mathrm{S}$ & 24.5 & 23.0 & 23.6 & 23.9 & 26.0 & 28.7 & 29.5 & 30.8 & 33.3 & 33.9 & 32.1 & 28.7 \\
\hline $15^{\circ} \mathrm{S}-20^{\circ} \mathrm{S}$ & 26.6 & 24.7 & 24.8 & 25.2 & 27.1 & 29.8 & 31.0 & 32.5 & 35.5 & 36.4 & 34.2 & 30.5 \\
\hline $20^{\circ} \mathrm{S}-25^{\circ} \mathrm{S}$ & 29.8 & 27.9 & 27.6 & 27.6 & 28.7 & 30.9 & 32.7 & 35.1 & 38.2 & 39.5 & 37.3 & 33.5 \\
\hline $25^{\circ} \mathrm{S}-30^{\circ} \mathrm{S}$ & 32.4 & 30.6 & 29.9 & 29.3 & 29.8 & 31.4 & 34.2 & 36.8 & 40.2 & 41.2 & 39.3 & 36.2 \\
\hline $30^{\circ} \mathrm{S}-35^{\circ} \mathrm{S}$ & 33.9 & 31.8 & 30.5 & 28.6 & 28.3 & 30.0 & 33.4 & 36.2 & 38.9 & 39.5 & 37.5 & 35.9 \\
\hline $35^{\circ} \mathrm{S}-40^{\circ} \mathrm{S}$ & 32.2 & 30.4 & 28.4 & 26.4 & 26.2 & 27.6 & 30.7 & 33.9 & 35.4 & 35.0 & 32.5 & 31.7 \\
\hline $40^{\circ} \mathrm{S}-45^{\circ} \mathrm{S}$ & 28.0 & 27.2 & 26.0 & 25.6 & 25.6 & 26.5 & 28.5 & 30.5 & 31.6 & 30.3 & 28.3 & 27.1 \\
\hline $45^{\circ} \mathrm{S}-50^{\circ} \mathrm{S}$ & 25.6 & 25.8 & 25.7 & 25.9 & 25.8 & 25.9 & 26.7 & 28.2 & 30.6 & 29.9 & 28.0 & 25.8 \\
\hline $50^{\circ} \mathrm{S}-55^{\circ} \mathrm{S}$ & 25.3 & 26.5 & 27.8 & 27.5 & 27.8 & 29.7 & 28.5 & 28.0 & 31.4 & 30.7 & 28.4 & 25.4 \\
\hline $55^{\circ} \mathrm{S}-60^{\circ} \mathrm{S}$ & 23.6 & 26.5 & 28.4 & 26.8 & 28.6 & 28.5 & 29.4 & 28.8 & 30.2 & 29.5 & 26.7 & 23.7 \\
\hline $60^{\circ} \mathrm{S}-65^{\circ} \mathrm{S}$ & 22.6 & 25.8 & 27.5 & 26.6 & 29.8 & 33.2 & 33.6 & 28.3 & 27.0 & 31.2 & 25.8 & 22.0 \\
\hline
\end{tabular}

the SH subtropics during September-November (>39 DU). There is a transition in the NH from peak values in spring months (March-May) in the tropics/subtropics to peak values in summer (June-July) in the mid-latitudes. This pattern shift from spring to summer with latitude is caused largely by a coupling of spring-summer stratosphere-troposphere exchange with ozone produced from pollution events in summer months. We note that the GMI modeled ozone and OMI/MLS tropospheric ozone evaluated by Ziemke et al. (2006) showed the same basic temporal and spatial features in Fig. 7 despite the modeled ozone field being 5$10 \mathrm{DU}$ higher than OMI/MLS values at NH mid-latitudes. Table 2 lists the calculated zonal mean TCO climatology values plotted in Fig. 7.

Calculated zonal mean TCO climatology as a function of latitude at three-month intervals (January, April, July, and October) is shown in Fig. 8. Also included in Fig. 8 are zonally averaged $\pm 2 \sigma$ vertical bars for TCO where $\sigma$ represents the calculated 6-year RMS standard error of the mean at a given grid point. The RMS $\pm 2 \sigma$ values in Fig. 8 provide a measure of inter-annual variability of TCO with average peak-to-peak changes of about $3 \mathrm{DU}$.

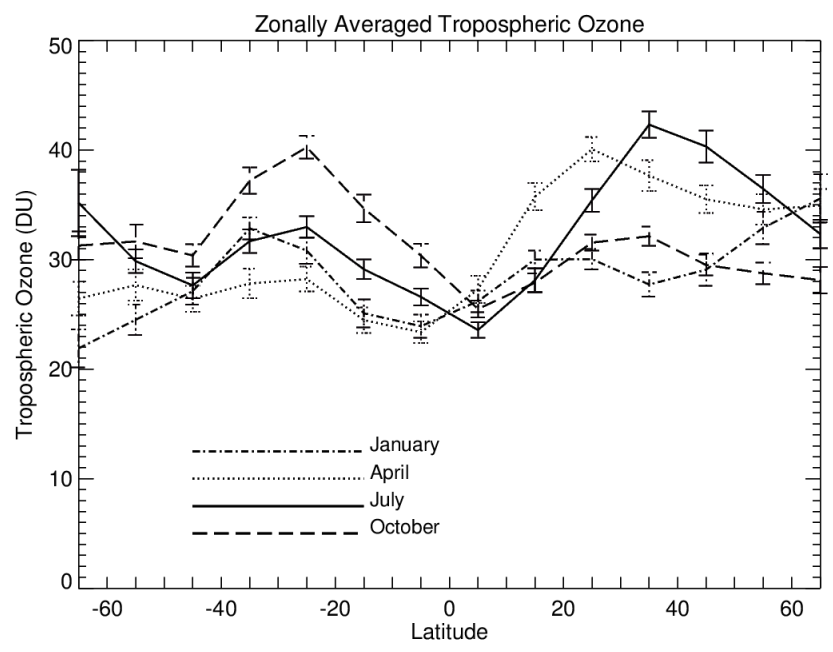

Fig. 8. Calculated zonal mean TCO climatology as function of latitude at three-month intervals (January, April, July, and October). Also plotted are zonally averaged $\pm 2 \sigma$ vertical bars for TCO where $\sigma$ represents calculated six-year RMS standard error of the mean at a given grid point. These zonal mean values and $\pm 2 \sigma$ values are derived from the $10^{\circ} \times 10^{\circ}$ gridded product. 

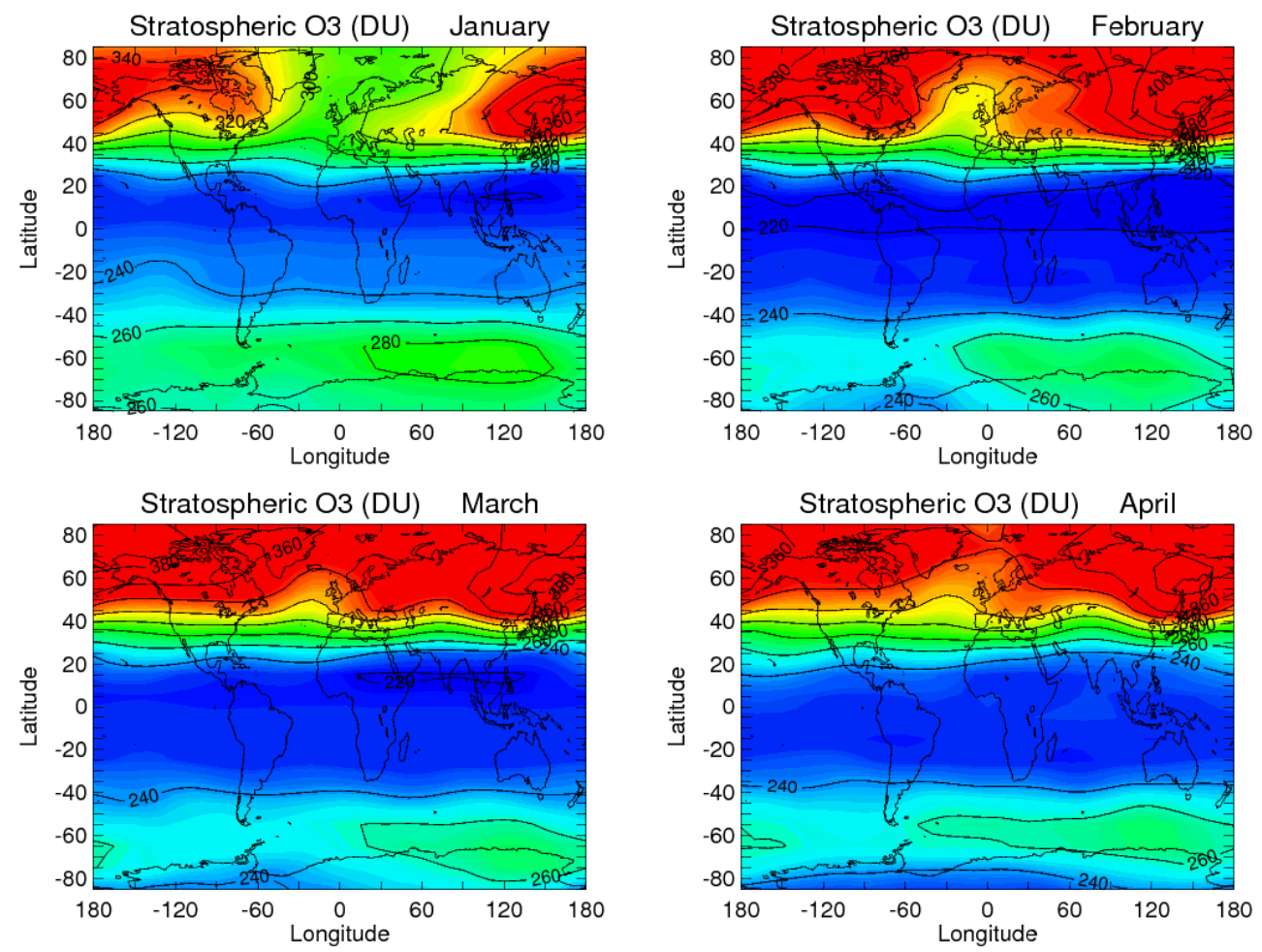

Fig. 9a. Similar to Fig. 5a but for stratospheric column ozone (in Dobson Units). The colors in the panels going from blue to red represent smallest to largest values, respectively.

\section{MLS global SCO climatology maps}

An SCO climatology from MLS is shown in Fig. 9a-c for every month of the year. As in Fig. 5 the data binning is at $10^{\circ} \times 10^{\circ}$ resolution which for SCO provides nearly global coverage out to latitudes $\pm 85^{\circ}$. The main features include a contrast between small zonal variability of SCO in the tropics and large planetary-scale variability in the middle and high latitudes in both hemispheres. SCO in Fig. 9 should be interpreted carefully in the middle and high latitudes because of substantial inter-annual differences in zonal variability caused by stratospheric sudden warming events and the morphology of the breakup of the middle atmosphere polar vortex in the NH and SH. Zonal mean SCO from MLS is shown in Fig. 10 and is largest during the spring months in both hemispheres. SCO is observed to be largest in both hemispheres during spring. The maximum SCO in the $\mathrm{NH}$ occurs in conjunction with high ozone over the central Asian continent extending eastward across North America as shown in Fig. 9a. SCO in the SH maximizes equatorward of the polar vortex in September-October and as Fig. 9c shows, originates primarily from the Pacific centered near the dateline. Table 3 lists the calculated zonal mean SCO climatology values plotted in Fig. 10. Figure 11 plots calculated zonal mean SCO climatology as a function of latitude at three-month intervals (January, April, July, and October). Also included in Fig. 11 are zonally averaged $\pm 2 \sigma$ vertical bars for SCO where $\sigma$ represents calculated 6-year RMS standard error of mean at a given grid point. The $\pm 2 \sigma$ RMS numbers in Fig. 11 provide a measure of inter-annual variability of SCO with average peak-to-peak changes varying from about $10 \mathrm{DU}$ to $25 \mathrm{DU}$.

\section{Summary}

A six-year global climatology of tropospheric column ozone (TCO) and stratospheric column ozone (SCO) is derived from residual differences of column ozone from the Aura OMI and MLS instruments for October 2004-December 2010. This climatology was tested against nearly 40 ozonesonde stations from the SHADOZ and WOUDC networks and also the Labow-Logan-McPeters (LLM) zonal mean troposphere-stratosphere climatology. The comparisons of TCO between our climatology and these other data products indicate closely similar signatures for seasonal cycles and spatial variability, although there are offset differences exceeding $5 \mathrm{DU}$, particularly in the high latitudes which are not currently resolved.

Largest TCO (exceeding 40-50 DU) in the climatology lies in the tropical south Atlantic during September-October and in the Mediterranean and east China/Japan region during May-August. Smallest TCO of 15-25 DU persists in the 
Table 3. Global stratospheric column ozone zonal mean monthly mean climatology (in Dobson Units) derived from MLS integrated ozone profiles at $5^{\circ}$ latitude resolution.

\begin{tabular}{|c|c|c|c|c|c|c|c|c|c|c|c|c|}
\hline Latitudes & Jan & Feb & Mar & Apr & May & Jun & Jul & Aug & Sep & Oct & Nov & Dec \\
\hline $85^{\circ} \mathrm{N}-90^{\circ} \mathrm{N}$ & 311 & 350 & 352 & 340 & 324 & 297 & 269 & 253 & 243 & 246 & 267 & 279 \\
\hline $80^{\circ} \mathrm{N}-85^{\circ} \mathrm{N}$ & 314 & 363 & 361 & 359 & 330 & 300 & 269 & 252 & 244 & 251 & 270 & 281 \\
\hline $75^{\circ} \mathrm{N}-80^{\circ} \mathrm{N}$ & 319 & 363 & 363 & 359 & 330 & 301 & 272 & 254 & 248 & 254 & 275 & 287 \\
\hline $70^{\circ} \mathrm{N}-75^{\circ} \mathrm{N}$ & 326 & 359 & 361 & 359 & 333 & 303 & 275 & 262 & 256 & 259 & 279 & 293 \\
\hline $65^{\circ} \mathrm{N}-70^{\circ} \mathrm{N}$ & 330 & 359 & 359 & 355 & 332 & 304 & 280 & 269 & 262 & 265 & 280 & 299 \\
\hline $60^{\circ} \mathrm{N}-65^{\circ} \mathrm{N}$ & 333 & 359 & 359 & 352 & 331 & 306 & 286 & 274 & 267 & 269 & 283 & 306 \\
\hline $55^{\circ} \mathrm{N}-60^{\circ} \mathrm{N}$ & 332 & 355 & 354 & 347 & 329 & 307 & 291 & 277 & 270 & 270 & 282 & 309 \\
\hline $50^{\circ} \mathrm{N}-55^{\circ} \mathrm{N}$ & 329 & 349 & 348 & 340 & 325 & 306 & 290 & 276 & 267 & 267 & 279 & 308 \\
\hline $45^{\circ} \mathrm{N}-50^{\circ} \mathrm{N}$ & 321 & 338 & 338 & 331 & 318 & 299 & 280 & 269 & 262 & 260 & 273 & 302 \\
\hline $40^{\circ} \mathrm{N}-45^{\circ} \mathrm{N}$ & 307 & 320 & 324 & 318 & 304 & 286 & 266 & 259 & 254 & 252 & 265 & 289 \\
\hline $35^{\circ} \mathrm{N}-40^{\circ} \mathrm{N}$ & 284 & 292 & 300 & 298 & 286 & 271 & 256 & 252 & 248 & 243 & 252 & 269 \\
\hline $30^{\circ} \mathrm{N}-35^{\circ} \mathrm{N}$ & 257 & 262 & 272 & 275 & 269 & 259 & 251 & 248 & 244 & 237 & 237 & 247 \\
\hline $25^{\circ} \mathrm{N}-30^{\circ} \mathrm{N}$ & 234 & 238 & 248 & 255 & 256 & 252 & 248 & 246 & 242 & 234 & 229 & 230 \\
\hline $20^{\circ} \mathrm{N}-25^{\circ} \mathrm{N}$ & 221 & 224 & 234 & 242 & 246 & 246 & 245 & 244 & 240 & 232 & 224 & 219 \\
\hline $15^{\circ} \mathrm{N}-20^{\circ} \mathrm{N}$ & 215 & 218 & 227 & 235 & 240 & 242 & 244 & 245 & 241 & 232 & 223 & 215 \\
\hline $10^{\circ} \mathrm{N}-15^{\circ} \mathrm{N}$ & 214 & 216 & 224 & 232 & 237 & 240 & 244 & 245 & 242 & 232 & 223 & 214 \\
\hline $5^{\circ} \mathrm{N}-10^{\circ} \mathrm{N}$ & 215 & 217 & 223 & 230 & 234 & 237 & 240 & 242 & 240 & 231 & 224 & 216 \\
\hline $0^{\circ}-5^{\circ} \mathrm{N}$ & 219 & 221 & 226 & 231 & 232 & 233 & 236 & 238 & 237 & 229 & 225 & 219 \\
\hline $0^{\circ}-5^{\circ} \mathrm{S}$ & 223 & 224 & 228 & 231 & 230 & 229 & 230 & 233 & 233 & 228 & 225 & 222 \\
\hline $5^{\circ} \mathrm{S}-10^{\circ} \mathrm{S}$ & 225 & 226 & 228 & 229 & 227 & 224 & 225 & 228 & 230 & 228 & 227 & 225 \\
\hline $10^{\circ} \mathrm{S}-15^{\circ} \mathrm{S}$ & 227 & 227 & 227 & 227 & 223 & 221 & 223 & 226 & 230 & 229 & 230 & 228 \\
\hline $15^{\circ} \mathrm{S}-20^{\circ} \mathrm{S}$ & 228 & 226 & 226 & 225 & 222 & 222 & 225 & 228 & 234 & 234 & 233 & 230 \\
\hline $20^{\circ} \mathrm{S}-25^{\circ} \mathrm{S}$ & 228 & 225 & 225 & 225 & 224 & 226 & 230 & 235 & 242 & 241 & 239 & 232 \\
\hline $25^{\circ} \mathrm{S}-30^{\circ} \mathrm{S}$ & 229 & 226 & 227 & 228 & 229 & 234 & 239 & 248 & 254 & 251 & 247 & 237 \\
\hline $30^{\circ} \mathrm{S}-35^{\circ} \mathrm{S}$ & 232 & 230 & 231 & 233 & 239 & 249 & 255 & 267 & 271 & 267 & 259 & 243 \\
\hline $35^{\circ} \mathrm{S}-40^{\circ} \mathrm{S}$ & 238 & 235 & 236 & 240 & 250 & 265 & 275 & 288 & 292 & 287 & 274 & 252 \\
\hline $40^{\circ} \mathrm{S}-45^{\circ} \mathrm{S}$ & 248 & 242 & 241 & 247 & 259 & 276 & 290 & 303 & 308 & 304 & 288 & 263 \\
\hline $45^{\circ} \mathrm{S}-50^{\circ} \mathrm{S}$ & 260 & 250 & 247 & 255 & 267 & 282 & 298 & 310 & 316 & 313 & 298 & 273 \\
\hline $50^{\circ} \mathrm{S}-55^{\circ} \mathrm{S}$ & 269 & 257 & 252 & 259 & 270 & 282 & 294 & 305 & 314 & 313 & 302 & 280 \\
\hline $55^{\circ} \mathrm{S}-60^{\circ} \mathrm{S}$ & 275 & 262 & 257 & 262 & 271 & 278 & 281 & 284 & 290 & 299 & 299 & 283 \\
\hline $60^{\circ} \mathrm{S}-65^{\circ} \mathrm{S}$ & 274 & 264 & 258 & 261 & 269 & 273 & 264 & 247 & 242 & 271 & 283 & 280 \\
\hline $65^{\circ} \mathrm{S}-70^{\circ} \mathrm{S}$ & 269 & 261 & 257 & 256 & 263 & 264 & 247 & 211 & 186 & 233 & 254 & 273 \\
\hline $70^{\circ} \mathrm{S}-75^{\circ} \mathrm{S}$ & 264 & 257 & 257 & 250 & 254 & 253 & 235 & 198 & 150 & 196 & 224 & 267 \\
\hline $75^{\circ} \mathrm{S}-80^{\circ} \mathrm{S}$ & 259 & 253 & 252 & 242 & 247 & 244 & 226 & 196 & 135 & 173 & 205 & 260 \\
\hline $80^{\circ} \mathrm{S}-85^{\circ} \mathrm{S}$ & 258 & 252 & 246 & 237 & 238 & 237 & 225 & 202 & 134 & 147 & 190 & 256 \\
\hline $85^{\circ} \mathrm{S}-90^{\circ} \mathrm{S}$ & 252 & 246 & 237 & 230 & 237 & 236 & 225 & 204 & 135 & 142 & 187 & 252 \\
\hline
\end{tabular}

tropical Pacific year round and high southern latitudes during summer. Largest SCO exceeding 360-400 DU lies in the Northern Hemisphere and extends from the eastern Asian continent eastward across the Pacific Ocean and North America during winter and spring. Smallest SCO less than 220 DU lies in the tropics year-round with much smaller SCO less than $150 \mathrm{DU}$ (for $10^{\circ}$ latitude-band zonal means) occurring in September-October in the Antarctic associated with the ozone hole. An important characteristic in the tropics is that there is almost no zonal variability of SCO (i.e., only a few DU at most) while there is large zonal variability of TCO (i.e., 35-50 DU in the Atlantic with $~ 15-20$ DU in Pacific in all months). We have calculated a 6-year RMS standard error of the mean $(\sigma)$ at each grid point for the TCO and SCO climatology. This statistic provides a measure of inter-annual variability and indicates peak-to-peak changes $( \pm 2 \sigma)$ of about 3 DU on average for TCO and about $10 \mathrm{DU}$ to $25 \mathrm{DU}$ for SCO (largest values in high latitudes in winterspring).

The derived ozone climatology is useful for several purposes including evaluation of the performance of 3-D chemistry-transport models and global circulation models of the ocean-atmosphere. By comparing seasonal cycles and seasonally-varying spatial variability of TCO and SCO from the climatology one can identify and correct problems in the models involving errors in wind fields, errors in coded photochemical reaction rates, stratosphere-troposphere exchange, boundary layer dynamics and chemistry, and emissions 

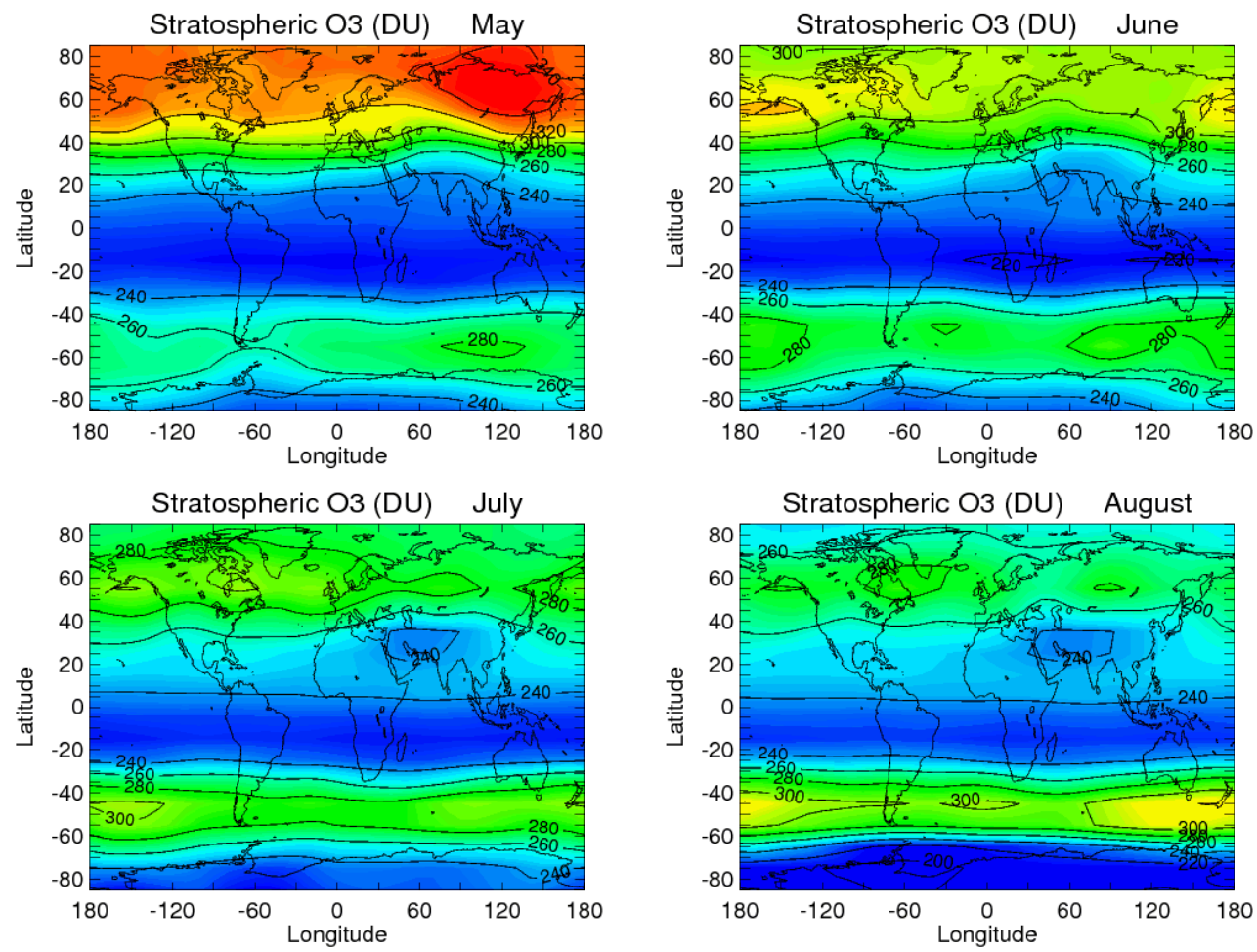

Fig. 9b. Similar to Fig. 5b but for stratospheric column ozone (in Dobson Units).
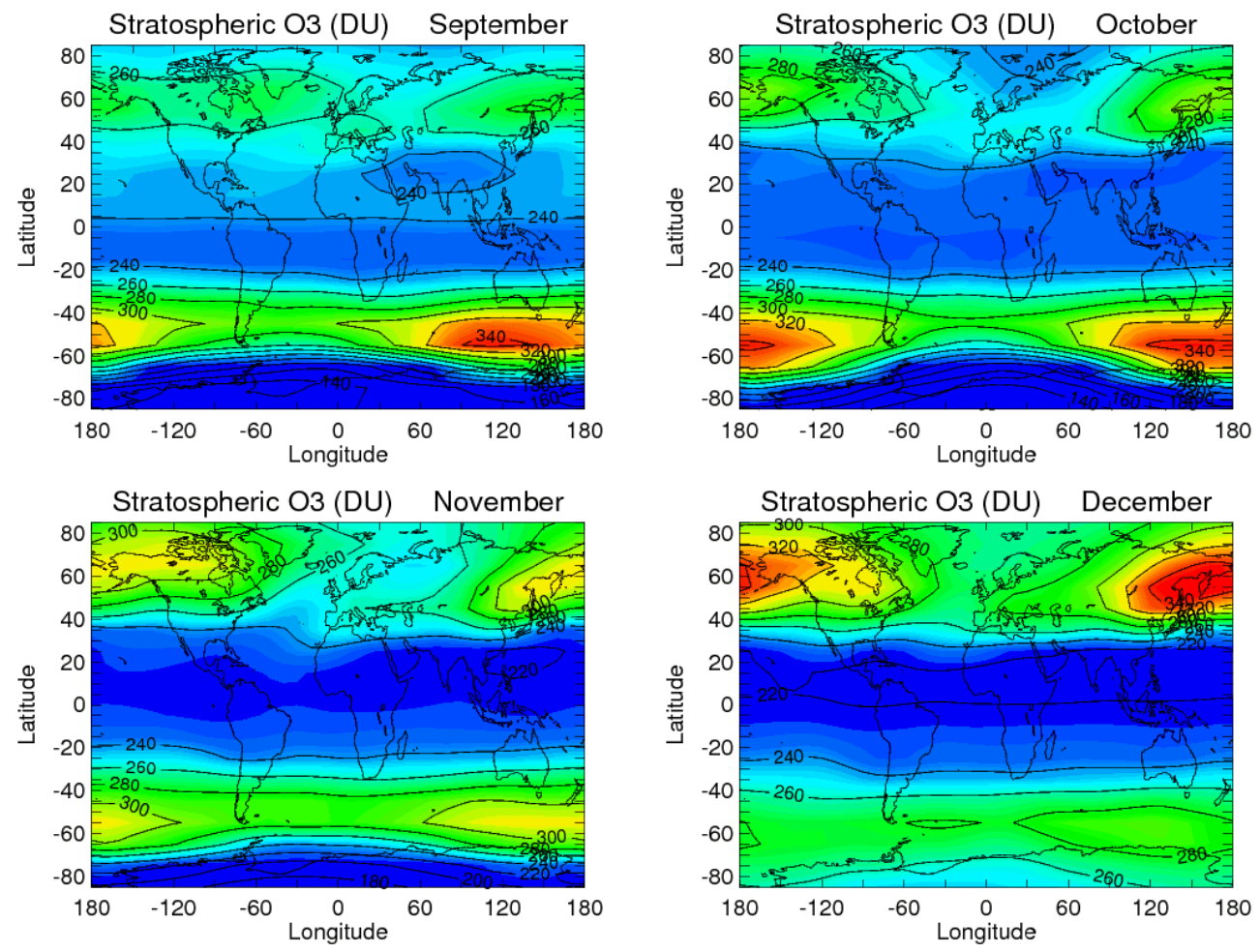

Fig. 9c. Similar to Fig. 5c but for stratospheric column ozone (in Dobson Units). 


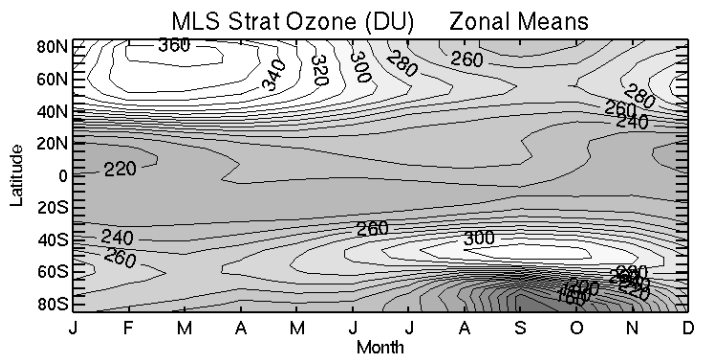

Fig. 10. Zonal mean climatology of stratospheric column ozone (in Dobson Units) from October 2004-December 2010 MLS at $5^{\circ}$ latitude resolution. The shading going from dark to light represents smallest to largest values, respectively.

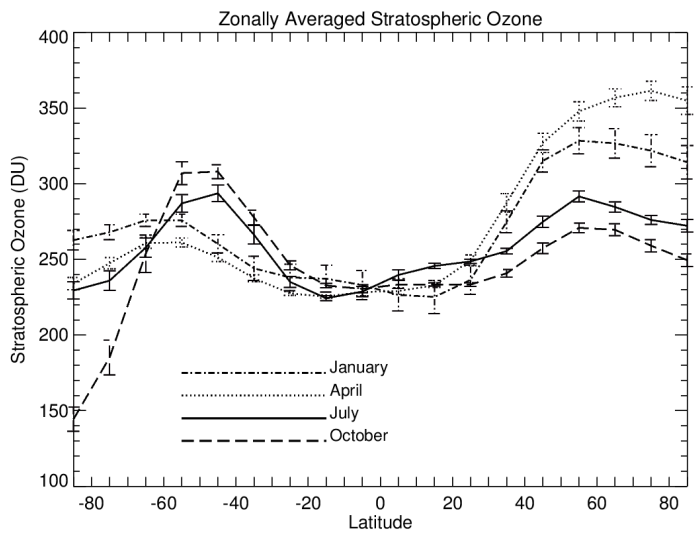

Fig. 11. Calculated zonal mean SCO climatology as function of latitude at three-month intervals (January, April, July, and October). Also plotted are zonally averaged $\pm 2 \sigma$ vertical bars for SCO where $\sigma$ represents calculated six-year RMS standard error of the mean at a given grid point. These zonal mean values and $\pm 2 \sigma$ values are derived from the $10^{\circ} \times 10^{\circ}$ gridded product.

inventories including ozone precursors. Other applications for the climatology include evaluation of global radiative forcing related to upper and lower atmospheric ozone and global clear-sky surface UV climatology as function of region and time of year. Algorithms for retrieving ozone from satellite remote sensing rely on assumed a priori information of the ozone concentrations. The current OMTO3 algorithm for OMI invokes the LLM climatology which is determined by combining ozonesondes with SAGE and Aura MLS ozone profile measurements and is given as a function of month, latitude, and altitude. A future task is to combine the LLM and OMI/MLS climatology products to generate a single 3-D (latitude, longitude, altitude) 12-month ozone profile climatology.

The $5^{\circ} \times 5^{\circ}$ and $10^{\circ} \times 10^{\circ}$ monthly TCO and SCO climatology fields along with their RMS fields can be obtained via the tropospheric ozone link from the NASA Goddard Space Flight Center ozone and air quality web page http://ozoneaq.gsfc.nasa.gov. This web site also includes the NCEP tropopause pressure fields at these same resolutions.
Acknowledgements. We want to thank the Aura MLS and OMI instrument and algorithm teams for the extensive satellite measurements used in this study. We also thank the SHADOZ and WOUDC ozonesonde and NCEP analyses teams for their data and analyses products used in this study. Work at the Jet Propulsion Laboratory, California Institute of Technology, was performed under contract with NASA. OMI is a Dutch-Finnish contribution to the Aura mission. Funding for this research was provided in part by NASA NNH07ZDA001N-AST.

Edited by: W. Lahoz

\section{References}

Avery, M., Twohy, C., McCabe, D., Joiner, J., Severance, K., Atlas, E., Blake, D., Bui, T. P., Crounse, J., Dibb, J., Diskin, G., Lawson, P., McGill, M., Rogers, D., Sachse, G., Scheuer, E., Thompson, A. M., Trepte, C., Wennberg, P., and Ziemke, J.: Convective distribution of tropospheric ozone and tracers in the Central American ITCZ region: Evidence from observations during TC4, J. Geophys. Res., 115, D00J21, doi:10.1029/2009JD013450, 2010.

Chandra, S., Ziemke, J. R. and Martin, R. V.: Tropospheric ozone at tropical and middle latitudes derived from TOMS/MLS residual: Comparison with a global model, J. Geophys. Res., 108(D9), 4291, doi:10.1029/2002JD002912, 2003.

Chandra, S., Ziemke, J. R., Duncan, B. N., Diehl, T. L., Livesey, N. J., and Froidevaux, L.: Effects of the 2006 El Niño on tropospheric ozone and carbon monoxide: implications for dynamics and biomass burning, Atmos. Chem. Phys., 9, 4239-4249, doi:10.5194/acp-9-4239-2009, 2009.

Doughty, D. C., Thompson, A. M., Schoeberl, M. R., Stajner, I., Wargan, K., and Hui, W. C. J.: An intercomparison of tropospheric ozone retrievals derived from two Aura instruments and measurements in western North America in 2006, J. Geophys. Res., 116, D06303, doi:10.1029/2010JD014703, 2011.

Fioletov, V. E., Labow, G. J., Evans, R., Hare, E. W., Ko“hler, U., McElroy, C. T., Miyagawa, K., Redondas, A., Savastiouk, V., Shalamyansky, A. M., Staehelin, J., Vanicek, K., and Weber, M.: Performance of the ground-based total ozone network assessed using satellite data, J. Geophys. Res., 113, D14313, doi:10.1029/2008JD009809, 2008.

Fishman, J., Watson, C. E., Larsen, J. C., and Logan,, J. A.: Distribution of tropospheric ozone determined from satellite data, J. Geophys. Res., 95, 3599-3617, 1990.

Fishman, J., Wozniak, A. E., and Creilson, J. K.: Global distribution of tropospheric ozone from satellite measurements using the empirically corrected tropospheric ozone residual technique: Identification of the regional aspects of air pollution, Atmos. Chem. Phys., 3, 893-907, doi:10.5194/acp-3-893-2003, 2003.

Froidevaux, L., Jiang, Y. B., Lambert, A., Livesey, N. J., Read, W. G., Waters, J. W., Browell, E. V., Hair, J. W., Avery, M. A., McGee, T. J., Twigg, L. W., Sumnicht, G. K., Jucks, K. W., Margitan, J. J., Sen, B., Stachnik, R. A., Toon, G. C., Bernath, P. F., Boone, C. D., Walker, K. A., Filipiak, M. J., Harwood, R. S., Fuller, R. A., Manney, G. L., Schwartz, M. J., Daffer, W. H., Drouin, B. J., Cofield, R. E., Cuddy, D. T., Jarnot, R. F., Knosp, B. W., Perun, V. S., Snyder, W. V., Stek, P. C., Thurstans, R. P., and Wagner, P. A.: Validation of Aura Microwave Limb 
Sounder stratospheric ozone measurements, J. Geophys. Res. 113, D15S20, doi:10.1029/2007JD008771, 2008.

Joiner, J. and Vasilkov, A. P.: First results from the OMI Rotational Raman Scattering Cloud Pressure Algorithm, IEEE T. Geosci. Remote, 44, 1272-1282, 2006.

Kar, J., Fishman, J., Creilson, J. K., Richter, A., Ziemke, J., and Chandra, S.: Are there urban signatures in the tropospheric ozone column products derived from satellite measurements?, Atmos. Chem. Phys., 10, 5213-5222, doi:10.5194/acp-10-5213-2010, 2010.

Kulawik, S. S., Worden, H., Osterman, G., Luo, M., Beer, R., Kinnison, D. E., Bowman, K. W., Worden, J., Eldering, A., Lampel, M., Steck, T., and Rodgers, C. D.: TES atmospheric profile retrieval characterization: An orbit of simulated observations, IEEE T. Geosci. Remote, 44, 1324-1333, 2006.

Levelt, P. F., Hilsenrath, E. Leppelmeier, G. W., van den Oord, G. H. J., Bhartia, P. K., Tamminen, J., de Haan, J. F., and Veefkind, J. P.: Science objectives of the Ozone Monitoring Instrument, IEEE T. Geophys. Remote, 44(5), 1199-1208, 2006.

Liu, X., Chance, K., Sioris, C. E., Kurosu, T. P., Spurr, R. J. D., R. V., Martin, Fu, T-M., Logan, J. A., Jacob, D. J., Palmer, P. I., Newchurch, M. J., Megretskaia, I. A., and Chatfield, R. B.: First directly retrieved global distribution of tropospheric column ozone from GOME: Comparison with the GEOS-CHEM model, J. Geophys. Res., 111, D02308, doi:10.1029/2005JD006564, 2006.

Liu, X., Bhartia, P. K., Chance, K., Spurr, R. J. D., and Kurosu, T. P.: Ozone profile retrievals from the Ozone Monitoring Instrument, Atmos. Chem. Phys., 10, 2521-2537, doi:10.5194/acp-10-25212010, 2010.

Logan, J. A.: An analysis of ozonesonde data for the troposphere: Recommendations for testing 3-D models, and development of a gridded climatology for tropospheric ozone, J. Geophys. Res., 104, 16115-16149, 1999.

Martin, R. V., Sauvage, B., Folkins, I., Sioris, C. E., Boone, C., Bernath, P., and Ziemke, J.: Space-based constraints on the production of nitric oxide by lightning, J. Geophys. Res., 112, D09309, doi:10.1029/2006JD007831, 2007.

McPeters, R. D., Labow, G. J., and Logan, J. A.: Ozone climatological profiles for satellite retrieval algorithms, J. Geophys. Res., 112, D05308, doi:10.1029/2005JD006823, 2007.

Sauvage, B., Martin, R. V., van Donkelaar, A., and Ziemke, J. R.: Quantification of the factors controlling tropical tropospheric ozone and the South Atlantic maximum, J. Geophys. Res., 112(D11), D11309, doi:1029/2006JD008008, 2007.

Schoeberl, M. R., Douglass, A. R., Hilsenrath, E., Bhartia, P. K., Barnett, J., Beer, R., Waters, J., Gunson, M., Froidevaux, L., Gille, J., Levelt, P. F., and DeCola, P.: Overview of the EOS Aura Mission, IEEE T. Geosci. Remote, 44(5), 1066-1074, 2006.

Schoeberl, M. R., Ziemke, J. R., Bojkov, B., Livesey, N., Duncan, B., Strahan, S., Froidevaux, L., Kulawik, S., Bhartia, P. K., Chandra, S., Levelt, P. F., Witte, J. C., Thompson, A. M., Cuevas,E., Redondas, A., Tarasick, D. W., Davies, J., Bodeker, G., Hansen, G., Johnson, B. J., Oltmans, S. J., Vomel, H., Allaart, M., Kelder, H., Newchurch, M., Godin-Beekmann, S., Ancellet, G., Claude, H., Andersen, S. B., Kyro, E., Parrondos, M., Yela, M., Zablocki, G., Moore, D., Dier, H., von der Gathen, P., Viatte, P., Stubi, R., Calpini, B., Skrivankova, P., Dorokhov, V., De Backer, H., Schmidlin, F. J., Coetzee, G., Fujiwara, M., Thouret, V., Posny,
F., Morris, G., Merrill, J., Leong, C. P., Koenig-Langlo, G. and Joseph, E.: A trajectory-based estimate of the tropospheric ozone column using the residual method, J. Geophys. Res., 112, D24S49, doi:10.1029/2007JD008773, 2007.

Smit, H. G. J., Straeter, W., Johnson, B. J., Oltmans, S. J., Davies, J., Tarasick, D. W., Hoegger, B., Stubi, R., Schmidlin, F. J., Northam, T., Thompson, A. M., Witte, J. C., Boyd, I. and Posny, F.: Assessment of the performance of ECC-ozonesondes under quasi-flight conditions in the environmental simulation chamber: Insights from the Juelich Ozone Sonde Intercomparison Experiment (JOSIE), J. Geophys. Res., 112, D19306, doi:10.1029/2006JD007308, 2007.

Stajner, I., Wargan, K., and Pawson, S.: Assimilated ozone from EOS-Aura: Evaluation of the tropopause region and tropospheric columns, J. Geophys. Res., 113, D16S32, doi:10.1029/2007JD008863, 2008.

Thompson, A. M., Witte, J. C., McPeters, R. D., Oltmans, S. J., Schmidlin, F. J., Logan, J. A., Fujiwara, M., Kirchhoff, V. W. J. H., Posny, F., Coetzee, G. J. R., Hoegger, B., Kawakami, S., Ogawa, T., Johnson, B. J., Vömel H., and Labow, G. J.: Southern Hemisphere Additional Ozonesondes (SHADOZ) 1998-2000 tropical ozone climatology: 1. Comparison with Total Ozone Mapping Spectrometer (TOMS) and ground-based measurements, J. Geophys. Res., 108(D2), 8238, doi:10.1029/2001JD000967, 2003.

Waters, J. W., Froidevaux, L., Harwood, R. S., Jarnot, R. F., Pickett, H. M., Read, W. G., Siegel, P. H., Cofield, R. E., Filipiak, M. J., Flower, D. A., Holden, J. R., Lau, G. K., Livesey, N. J., Manney, G. L., Pumphrey, H. C., Santee, M. L., Wu, D. L., Cuddy, D. T., Lay, R. R., Loo, M. S., Perun, V. S., Schwartz, M. J., Stek, P. C., Thurstans, R. P., Boyles, M. A., Chandra, S., Chavez, M. C., Chen, G.-S., Chudasama, B. V., Dodge, R., Fuller, R. A., Girard, M. A., Jiang, J. H., Jiang, Y., Knosp, B. W., LaBelle, R. C., Lam, J. C., Lee, K. A., Miller, D., Oswald, J. E., Patel, N. C., Pukala, D. M., Quintero, O., Scaff, D. M., Snyder, W. V., Tope, M. C., Wagner, P. A., and Walch, M. J.: The Earth Observing System Microwave Limb Sounder (EOS MLS) on the Aura satellite, IEEE T. Geosci. Remote, 44(5), 1075-1092, 2006.

Zhang, L., Jacob, D. J., Liu, X., Logan, J. A., Chance, K., Eldering, A., and Bojkov, B. R.: Intercomparison methods for satellite measurements of atmospheric composition: application to tropospheric ozone from TES and OMI, Atmos. Chem. Phys., 10, 4725-4739, doi:10.5194/acp-10-4725-2010, 2010.

Ziemke, J. R., Chandra, S., Duncan, B. N., Froidevaux, L., Bhartia, P. K., Levelt, P. F., and Waters, J. W.: Tropospheric ozone determined from Aura OMI and MLS: Evaluation of measurements and comparison with the Global Modeling Initiative's Chemical Transport Model, J. Geophys. Res., 111, D19303, doi:10.1029/2006JD007089, 2006.

Ziemke, J. R., Chandra, S., Schoeberl, M. R., Froidevaux, L., Read, W. G., Levelt, P. F., and Bhartia, P. K. : Intra-seasonal variability in tropospheric ozone and water vapor in the tropics, Geophys. Res. Lett., 34, L17804, doi:10.1029/2007GL030965, 2007.

Ziemke, J. R., Chandra, S., Duncan, B. N., Schoeberl, M. R., Damon, M. R., Torres, O., and Bhartia, P. K.: Recent biomass burning events in the tropics and elevated concentrations of tropospheric ozone, Geophys. Res. Lett., 36, L15819, doi:10.1029/2009GL039303, 2009. 